\title{
Impacts of different ENSO flavors and tropical Pacific convection variability (ITCZ, SPCZ) on austral summer rainfall in South America, with a focus on Peru
}

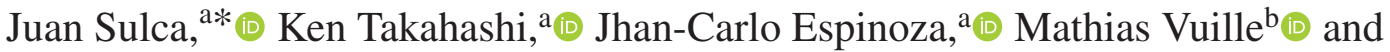 \\ Waldo Lavado-Casimiro ${ }^{\mathrm{C}}$ (1) \\ a Subdireccion de Ciencias de la Atmósfera e Hidrología, Instituto Geofisico del Perú, Lima, Peru \\ ${ }^{\mathrm{b}}$ Department of Atmospheric and Environmental Sciences, University at Albany-SUNY, NY, USA \\ c Servicio Nacional Meteorologia e Hidrologia (SENAMHI), Lima, Peru
}

\begin{abstract}
El Niño in the eastern and central Pacific has different impacts on the rainfall of South America, and the atmospheric pathways through the South Pacific Convergence Zone (SPCZ) and Inter-Tropical Convergence Zone (ITCZ) are poorly understood. To address this, we performed linear regression analysis of E (eastern Pacific) and C (central Pacific) indices of sea surface temperature (SST), as well as precipitation indices for the SPCZ and ITCZ, with gridded precipitation and reanalysis data sets during the austral summer (December-February) for the 1980-2016 period. Positive C induces dry anomalies along the tropical Andes and northern South America (NSA), while wet anomalies prevail over southeastern South America (SESA). Moreover, it produces wet conditions in the northwestern Peruvian Amazon. In contrast, positive E enhances wet conditions along the coasts of Ecuador and northern Peru associated with the southward displacement of the eastern Pacific ITCZ and induces dry conditions in Altiplano, Amazon basin, and northeastern Brazil (NEB). Both El Niño Southern Oscillation (ENSO) indices are associated with weakened upper-level easterly flow over Peru, but it is more restricted to the central and southern Peruvian Andes with positive E. Both SPCZ indices, the zonal position of the SPCZ and its latitudinal displacement, suppress rainfall along western Peruvian Andes when are positive, but the latter also inhibits rainfall over the Bolivian Altiplano. They are also linked to upper-level westerly wind anomalies overall of Peru, but these anomalies do not extend as far south in the first. The southward displacement of the eastern Pacific ITCZ also induces wet anomalies in SESA while dry anomalies prevail over NEB, the western Amazon basin, and Bolivia. Oppositely, the southward displacement of the central Pacific ITCZ induces dry anomalies in NEB and along the northern coast of Peru; while wet anomalies occur mainly in eastern Brazil, Paraguay, and Bolivia through an enhancement of the low level jet.
\end{abstract}

KEY WORDS rainfall; atmospheric teleconnections; ENSO; SPCZ; ITCZ; South America; Andes; Peru

Received 16 December 2016; Revised 18 May 2017; Accepted 30 May 2017

\section{Introduction}

The El Niño Southern Oscillation (ENSO) is a coupled ocean-atmosphere phenomenon originating in the tropical Pacific with global impacts. El Niño and La Niña represent the positive (warm) and negative (cool) phases of ENSO, respectively. Large-scale weather anomalies associated with El Niño and La Niña conditions have been documented around the globe through atmospheric and oceanic teleconnections, with significant impacts on society and natural system (Ropelewski and Halpert 1987; Trenberth et al., 1998; McPhaden et al., 2006).

The strongest El Niño rainfall anomalies in South America (SA) occur during the austral summer (December-January-February), which coincides approximately with the rainy season in tropical South America south of the equator, and are associated with heavy precipitation and flooding along the coast of northern

\footnotetext{
* Correspondence to: J. Sulca, Instituto Geofisico del Perú, Calle Badajoz 169, Mayorazgo IV Etapa, Ate Vitarte, 15012, Lima, Peru. E-mail: sulcaf5@gmail.com
}

Peru/southern Ecuador. These rainy events are associated with locally increased sea surface temperature (SST) (Carranza, 1891; Eguiguren, 1894; Vuille et al., 2000a), reaching unprecedented high levels in the 1982-1983 and 1997-1998 El Niño events (Goldberg et al., 1987; Takahashi, 2004; Douglas et al., 2009). For instance, Takahashi (2004) documented that the El Niño 1997-1998 caused $1802 \mathrm{~mm}$ of rainfall in the city of Piura, 30 times its normal value $(60 \mathrm{~mm})$. On the other hand, below average precipitation prevails in the tropical Andes during El Niño (e.g. Aceituno, 1988; Instituto Geofísico del Perú, 2005a), primarily due to upper-levels westerly wind anomalies (Vuille, 1999; Garreaud et al., 2009; Sulca et al., 2016). The same westerly wind anomalies and the associated precipitation deficit at same time also lead to negative glacier balance mass along the tropical Andes during El Niño (Francou et al., 2004; Vuille et al., 2008). The opposite tends to occur during La Niña due to significant easterly wind anomalies prevailing at upper tropospheric levels, thereby enhancing moisture influx from the east towards the Andes. 
On a larger scale, El Niño reduces rainfall in north/northeastern South America and enhances it in southeastern South America (SESA) (Zhou and Lau, 2001; Grimm and Ambrizzi, 2009; Grimm, 2011), the former associated with ENSO effects on the Atlantic SST and coupled responses (Enfield and Mayer, 1997; Giannini et al., 2001; Wang, 2005). For example, Giannini et al. (2001) numerically showed that the warm ENSO phase reduces rainfall in most parts of the tropical Atlantic basin because El Niño warms the free troposphere and thus forces the vertical stabilization of the tropical atmosphere. Furthermore, the warm phase of the ENSO enhances humidity flux from low latitudes to SESA through an enhanced South American low level jet (SALLJ) (Marengo et al., 2004; Silva and Ambrizzi, 2006; Silva et al., 2009), while the South Atlantic Convergence Zone (SACZ) at the same time moves southward of its climatological position (Robertson and Mechoso, 2000; Carvalho et al., 2004).

Recently, the scientific community has started to focus on the diversity among ENSO events in terms of their amplitude, temporal evolution, and spatial pattern (see review by Capotondi et al. (2015)). Particularly, the classification is focused on whether the maximum SST anomalies are located in the central or the eastern equatorial Pacific (Larkin and Harrison, 2005; Ashok et al., 2007; $\mathrm{Kao}$ and $\mathrm{Yu}, 2009$ ) in spite of the arbitrary separation, as most events lie in a continuum except for the most extreme events (Takahashi et al., 2011; Capotondi et al., 2015; Takahashi and Dewitte, 2016). Nevertheless, at least two indices are needed to adequately describe the large-scale Pacific SST pattern and evolution associated with the diverse ENSO flavors (Trenberth and Stepaniak, 2001; Takahashi et al., 2011).

The diversity in ENSO events also implies a wide range of atmospheric teleconnections worldwide (e.g. Larkin and Harrison, 2005; Ashok et al., 2007; Sun et al., 2013). In South America, several studies have analysed the different rainfall impacts associated with each type of ENSO such as Canonical El Niño and Modoki El Niño (e.g. Tedeschi et al., 2013; Córdoba-Machado et al., 2015; Tedeschi and Collins, 2016) and central El Niño and eastern El Niño (Tedeschi et al., 2015). For instance, Tedeschi et al. (2015) documented that central El Niño mainly provokes dry anomalies in northern and northeast Brazil (NEB), along the northern coast of Peru, the Peruvian Andes, Ecuadorian coast, northern Colombian Andes, and eastern slope of the south-central Andes (Bolivia, Chile, and Argentina); while wet anomalies prevail along the southwestern boundary of Brazil, eastern Paraguay, and SESA. This rainfall pattern in South America is consistent with the pattern of streamflow anomalies at upper tropospheric levels (at $200 \mathrm{hPa}$ ). For example, the dry conditions are in agreement with the westerly streamflow anomalies over the entire Peruvian Andes, Bolivia, northern Chile, and northern Argentina; and southerly streamflow anomalies around NEB and northern SA (Venezuela, Guyana, French Guiana, and Suriname). At the same time, a cyclonic streamflow anomaly prevails over the coast of southeastern Argentina and thus induces wet conditions in this region and over SESA. For east El Niño events, in contrast, Tedeschi et al. (2015) reported that westerly streamflow anomalies prevail over all of Peru and even across the entire continent towards the Atlantic Ocean. This latter aspect explains the dry anomalies in northern Brazil, the northwestern Amazon, Peruvian Andes, and Bolivia. These dry anomalies are more pronounced than during central El Niño events. Easterly and southeasterly vertically integrated moisture flux anomalies are consistent with wet anomalies over the northern coast of Peru and along the Ecuadorian coast. The wet anomalies over SESA are consistent with the northerly, vertically integrated moisture flux anomalies originating over Bolivia.

In Peru, the enhanced coastal and reduced Andean/ Amazonian rainfall are associated with surface warming in the eastern and central equatorial Pacific, respectively, which can both occur, with varying relative magnitudes, during El Niño or (with approximately the opposite sign) during La Niña (Lagos et al., 2008; Lavado et al., 2013; Rau et al., 2017). We should note that the Atlantic SST variability also plays a key role in modulating the South American climate such as over the Amazon region on several timescales (Espinoza et al., 2011; Marengo and Espinoza, 2016; Jiménez-Muñoz et al., 2016). For example, Marengo and Espinoza (2016) pointed out that drought or floods in the Amazon region tend to be explained as a result of the combined effect of the anomalous circulation associated with changes in SST of the tropical Pacific and Atlantic Oceans. For example, the 2010 drought in the Amazon originated as a result from the occurrence of El Niño during the 2009-2010 austral summer and the subsequent warming in the North Atlantic Ocean during austral autumn and winter. During the austral summer, Atlantic SST variability does not have an important influence on rainfall over the Altiplano region (Vuille et al., 2000a; Münnich and Neelin, 2005), the Peruvian central Andes (Instituto Geofísico del Perú, 2005b; Silva et al., 2008) or the Ecuadorian Andes (Vuille et al., 2000b). Indeed, teleconnections between SST in the tropical Pacific Ocean appear dominant in modulating rainfall variability in the Andean region, considering several timescales, from intra-seasonal to decadal (Garreaud, 1999; Segura et al., 2016; Sulca et al., 2016).

ENSO teleconnections are directly forced by the anomalies in convection and vertical motion in response to tropical SST anomalies, which force the stationary extra-tropical Rossby wave (e.g. Trenberth et al, 1998) and equatorial waves patterns (Gill, 1980). Recent studies indicate that ENSO teleconnections to North America are sensitive to the pattern of the convective response (Chiodi and Harrison, 2015; Johnson and Kosaka, 2016). In the Southern Hemisphere, where the climatological stationary wave pattern is not as pronounced, we could also expect a larger sensitivity to the specific pattern of the convective response to ENSO. For instance, ENSO modulates the strength and position of the South Pacific Convergence Zone (SPCZ) during the austral summer (Vincent et al., 2011; Widlansky et al., 2011; Van der Wiel et al., 2016) 
and the meridional displacement of the SPCZ is linked to the inter-annual precipitation variability in the central Andes (e.g. Garreaud and Aceituno, 2001; Vuille and Keimig, 2004). Even, on sub-seasonal timescales, Sulca et al. (2016) pointed out that dry spells in the Peruvian central Andes are associated with the northward displacement of the SPCZ during the austral summer. Moreover, Vera et al. (2004) showed that differences in ENSO impacts in South America in boreal spring are associated with the behaviour of the SPCZ and the propagation of stationary Rossby waves in the south Pacific and into South America. However, they did not analyse the influence of SPCZ on the impacts of ENSO on precipitation of South America during the austral summer. Analogously, ENSO modulates the strength and meridional position of the Inter-Tropical Convergence Zone (ITCZ) during the austral summer (Berry and Reeder, 2014). The ITCZ only moves into the South American continent during the extreme El Niño events (Takahashi and Battisti, 2007). So far, most of the observational and modelling studies focused on the impacts of the meridional displacement of the ITCZ on rainfall of NEB (Hastenrath and Heller, 1977; Moura and Shukla, 1981; Hastenrath and Greischar, 1993), the Colombian Andes (Poveda et al., 2005) and the northern coast of Peru (Philander, 1990). However, none of these studies assess the impacts of the central Pacific ITCZ by itself on the inter-annual variability of the precipitation of South America (SA).

Motivated by these considerations, the main objective of this study is to characterize the impacts of the different types of ENSO flavors on the precipitation in South America, particularly Peru, during the austral summer, as well as to diagnose the changes in the associated large-scale atmospheric circulation. Additionally, we attempt to isolate the contributions of the convective forcings associated with the SPCZ and Pacific ITCZ to these teleconnections. We expect that our study will contribute to improve the forecasting systems to mitigate the rainfall impacts associated with the different flavors of ENSO in this region.

In Section 2, we discuss the data and methods. Section 3 presents the results of our analysis of the physical mechanisms related to atmospheric teleconnections associated with changes in the spatial distribution of South American rainfall for each type of El Niño (E and C) during the austral summer. Section 4 presents the results of our analysis of the large-scale mechanisms linked to atmospheric teleconnections associated with changes in the spatial distribution of rainfall in South American continent for SPCZ and Pacific ITCZ indices. Section 5 discusses the results presented in the previous sections. Finally, Section 6 presents the summary and concluding remarks.

\section{Data and methodology}

To characterize the impacts of ENSO, SPCZ, and Pacific ITCZ on the inter-annual precipitation variability of Peru and the rest of South America during the austral summer (December-January-February, DJF), we used monthly gridded precipitation from the Global Precipitation Climatology Project (GPCP) and Climate Prediction Center (CPC)-merged analysis of precipitation (CMAP), which are described in Adler et al. (2003) and Xie and Arkin (1997), respectively. Both GPCP and CMAP data sets have a horizontal resolution of $2.5^{\circ} \times 2.5^{\circ}$, but differ slightly in the horizontal grid and period. Thus, we applied bilinear interpolation to the CMAP data set to compare both data sets for the period 1979-2016.

For South America, we also used the raingauge-based monthly gridded land precipitation from the University of Delaware version 4.02 (Matsuura and Willmott, 2015). This data set has a horizontal resolution of $0.5^{\circ} \times 0.5^{\circ}$ for the period 1900-2014 (http://climate.geog.udel.edu/ $\sim$ climate/html_pages/archive.html). For Peru, we used the PISCO (Peruvian-interpolated data of the SENAMHI's climatological and hydrological observations; Lavado et al., 2016) monthly gridded precipitation data set, which has a horizontal resolution of $0.05^{\circ} \times 0.05^{\circ}$ for the period 1981-2016 and is based on the rain gauge network data of the Servicio Nacional de Meteorología e Hidrología (SENAMHI) (freely available at ftp://ftp.senamhi.gob.pe/ PISCO_PREC). The resolution of this PISCO data allows the characterization of the spatial precipitation patterns associated with the Andean topography, where a complex spatial rainfall distribution is observed (e.g. Espinoza et al., 2015; Rau et al., 2017).

To characterize different ENSO flavors, we used the $\mathrm{E}$ and $\mathrm{C}$ indices for the eastern and central equatorial Pacific SST anomalies, respectively (Takahashi et al., 2011), calculated from the ERSST v3b data set and available at the IGP website (http://www.met.igp.gob.pe/datos/ EC.txt). We only used the index for the summer season (DJF), which is averaged between December and February of next year. The advantage of both $\mathrm{E}$ and $\mathrm{C}$ indices is that they have poor linear relationship among themselves. Both $\mathrm{E}$ and $\mathrm{C}$ indices, on the other hand, have been used by Lavado-Casimiro and Espinoza (2014) to isolate the impacts of SST variability on the precipitation of Peru, but their analysis was only using stations. We also downloaded the SST anomaly indices for the standard Niño 3.4 regions from NOAA CPC (http://www.cpc.ncep.noaa .gov/data/indices/ersst4.nino.mth.81-10.ascii). Our analysis is focused during the austral summer in the period 1980-2016.

Since the largest ENSO convective anomalies are associated with the displacement of the large-scale convergence zones (Trenberth and Caron, 2000), for the SPCZ, we used the latE and latW indices, which were defined in Vincent et al. (2011). The latE (latW) index is defined as the average latitude of the SPCZ when is localized inside $160^{\circ}-180^{\circ} \mathrm{E}\left(170^{\circ}-150^{\circ} \mathrm{W}\right)$. For the ITCZ, we defined two indices that measure its meridional displacement in the central-eastern and eastern Pacific. The ITCZC index for the central-eastern Pacific is defined as the difference between the average precipitation in the boxes $\left(153.75^{\circ}-123.75^{\circ} \mathrm{W}, 1.25^{\circ} \mathrm{S}-8.75^{\circ} \mathrm{N}\right)$ and $\left(153.75^{\circ}-123.75^{\circ} \mathrm{W}, 11.25^{\circ}-21.25^{\circ} \mathrm{N}\right)$. The ITCZE index for the eastern Pacific is defined as the precipitation mean 
in the $\left(118.75^{\circ}-91.25^{\circ} \mathrm{W}, 6.25^{\circ} \mathrm{S}-6.25^{\circ} \mathrm{N}\right)$ box. These four indices were calculated with the GPCP data.

To characterize the pattern of large-scale atmospheric circulation associated with ENSO, SPCZ, and ITCZ in DJF, we used ERA-Interim reanalysis, which are described in Dee et al. (2011), from the European Center for Medium-Range Weather Forecasts (ECMWF); which has a resolution of $0.75^{\circ} \times 0.75^{\circ}$ for the period 1979-2016. We focused on the 200-hPa horizontal wind and geopotential height, as well as on the vertically integrated moisture transport based on the monthly mean-specific humidity and horizontal wind data.

Our main analysis tool is linear regression of the spatial fields (precipitation, wind, geopotential height, and specific humidity) onto the indices. We calculated separately the linear regressions with $\mathrm{E}$ and $\mathrm{C}$, as well as with the Niño 3.4 index, for all of the fields described above. For the convective indices, we used multiple regressions with the four indices simultaneously as predictors (latE, latW, ITCZC, and ITCZE). The statistical significance of the regression coefficients corresponds to the $95 \%$ probability that these are different from 0 , based on the $90 \%$ confidence intervals provided by the regress function in Matlab (Chatterjee and Hadi, 1986). However, since the sample is small (37 summers) and the few extreme El Niño events (Takahashi et al., 2011) can have disproportionate effects on the regression, while the large spatial domains increase the chance of spurious correlations, aided by spatial correlations in the fields that affects the independence of the grid points (Bretherton et al., 1999), the significance is possibly overestimated in some cases. Therefore, this information is used primarily to guide us to focus on some notable features, while the physical interpretation provides a firmer basis for establishing their realism.

\section{Rainfall anomalies associated with the equatorial Pacific SST variability}

The regression field of the large-scale DJF precipitation with the Niño 3.4 index (Figure 1(a)) shows the well-known pattern with equatorward shift of the ITCZ, northeastward shift of the SPCZ, and eastward shift of the western Pacific warm-pool convection (e.g. Trenberth and Caron, 2000; Borlace et al., 2014) associated with warm events. In South America (Figure 1(d)), the dominant features are the reduction of precipitation in the north around $5^{\circ} \mathrm{S}$ (particularly in the northern Andes of Ecuador, western Colombia, eastern Venezuela, Guyana, Surinam, French Guiana, and northwestern Brazil), and the enhanced rainfall in SESA (southern Brazil, Uruguay, southeastern Paraguay, and northeastern Argentina). We also find an increase in rainfall along the coast of Ecuador and northern Peru, albeit weak (Figure 1(g)), which is associated with the projection of the southward-displaced ITCZ towards the coast (Figure 1(a)), while rainfall reduction prevails along the tropical Andes (Bolivia, Peru, and Ecuador). These findings are consistent with the previous studies described in Section 1. However, the rainfall increases in the northeastern Amazon of Peru during El Niño when is analysed with respect to the Niño 3.4 index (Figure $1(\mathrm{~g})$ ), but also when is based on the $\mathrm{E}$ and $\mathrm{C}$ indices (Figures 1(h) and (i)). This latter feature was not seen in previous studies, perhaps due to lack of in situ data in this region (Espinoza et al., 2009) or because satellite-derived cloudiness data was used, rather than precipitation (e.g. Frappart et al., 2012). This feature is also seen in the satellite-only TRMM 3B43 data set (1999-2016, Huffman et al., 2007; not shown) and is qualitatively consistent with realistic high-resolution climate models from the Geophysical Fluid Dynamics Laboratory (e.g. GFDL-CM2.5), which show this feature in the western Amazon and all along the eastern tropical Andes (Jia et al., 2015).

When we repeat the analysis using the $\mathrm{C}$ and $\mathrm{E}$ indices, similar large-scale features appear in the tropical Pacific, but shifted longitudinally (Figures 1(b) and (c)), consistent with the corresponding SST patterns (Takahashi and Dewitte, 2016). In particular, during warm events, both indices register a zonal rainfall dipole associated with the eastward shift of the western Pacific warm pool convection, with the nodes at $150^{\circ}$ and $170^{\circ} \mathrm{E}$ along the equator for $\mathrm{C}$ and $\mathrm{E}$, respectively (Figures 1(b) and (c)). Both indices are also associated with a northward shift of the SPCZ during warm events, although E produces a more widespread rainfall reduction in the diagonal portion of the SPCZ, leading to a more zonal configuration (Vincent et al., 2011; Borlace et al., 2014). In the case of the ITCZ, C is associated with equatorward displacement during warm events, mainly in the central-eastern Pacific $\left(170^{\circ}-120^{\circ} \mathrm{W}\right.$; Figure $\left.1(\mathrm{~b})\right)$, while $\mathrm{E}$ is associated with a southward displacement of the ITCZ all the way to the coast of Ecuador and northern Peru $\left(170^{\circ}-80^{\circ} \mathrm{W}\right.$; Figure 1(c)).

In South America, both $\mathrm{E}$ and $\mathrm{C}$ indices are associated with the reduced/enhanced rainfall in the northern/southeastern regions during their positive phase, although the signal is stronger for $\mathrm{C}$ than $\mathrm{E}$ (Figures 1(e) and (f)), but weaker than Niño 3.4 (Figure 1(d)), indicating that the latter provides a better depiction of these rainfall impacts. The positive phase of the $\mathrm{C}$ index explains most of the dry anomalies along the Andes of Peru and Ecuador, particularly over the western cordillera of Peru (Figure 1(h)). The positive phase of the E index on the other hand is associated with wet anomalies along the coasts of Ecuador and northern Peru, which is consistent with previous studies (Lagos et al., 2008; Lavado-Casimiro and Espinoza, 2014), and with dry conditions in the Peruvian Altiplano around Titicaca Lake (Figure 1(i)). The same Figure 1(i) shows that the positive phase of the $\mathrm{E}$ index is also negatively correlated with precipitation anomalies along the eastern Andean slopes of southern Peru and Bolivia, in the rainfall hotspots (Espinoza et al., 2015), as well as in the nearby Amazon plains. Both indices contribute to the rainfall enhancement in the northeastern Amazon of Peru during their positive phase (Figures 1(h) and (i)), but the Niño 3.4 index produces a stronger signal than either of the other two (Figure 1(g)). 

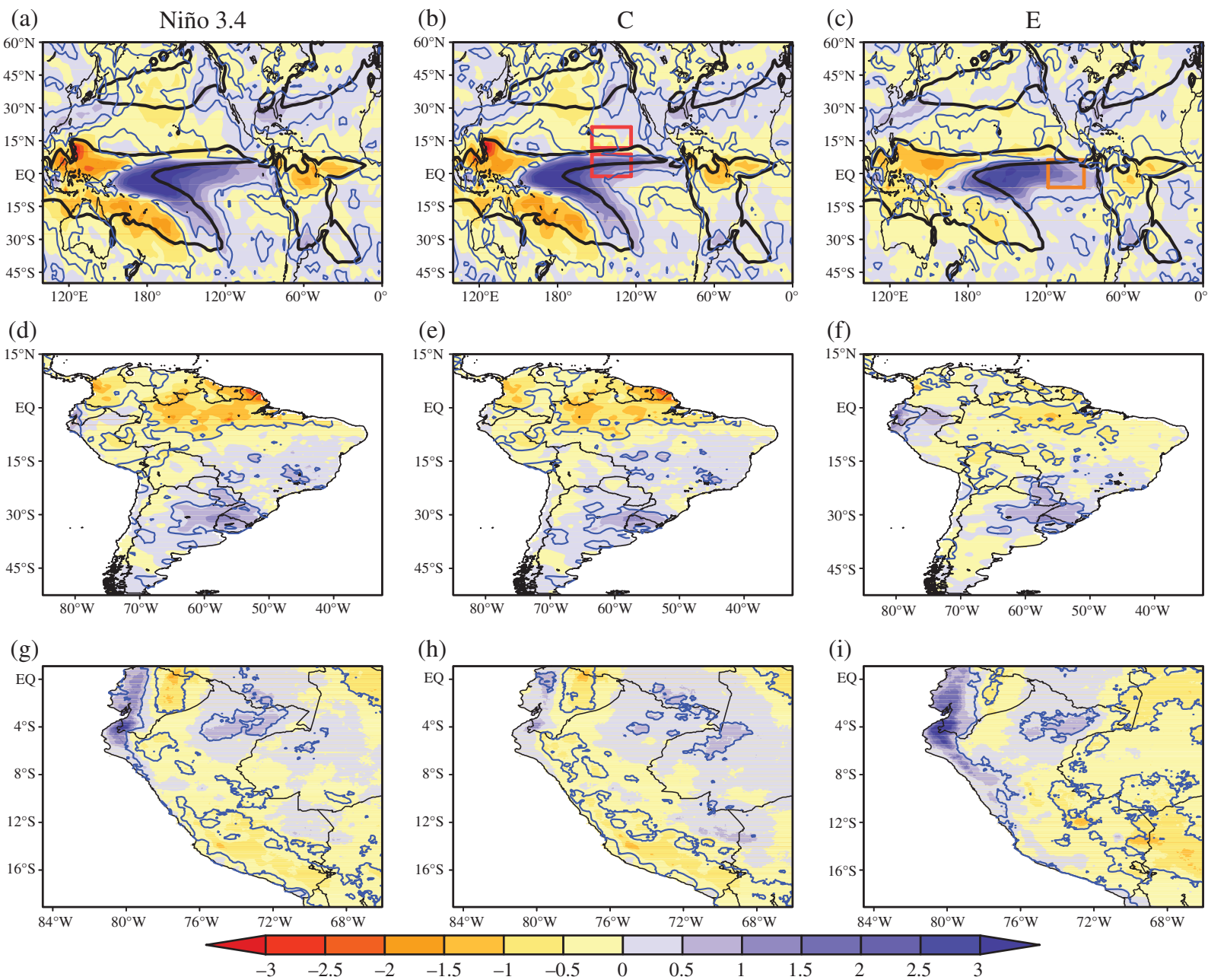

(h)

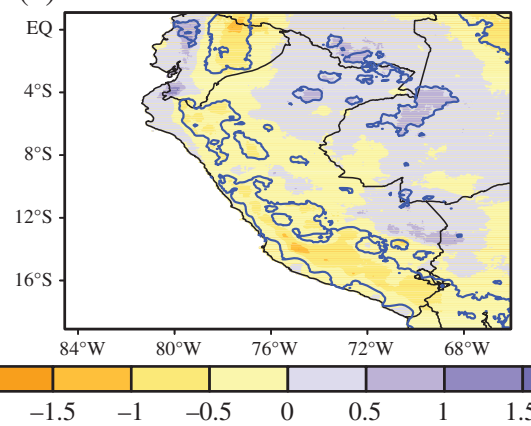

(i)

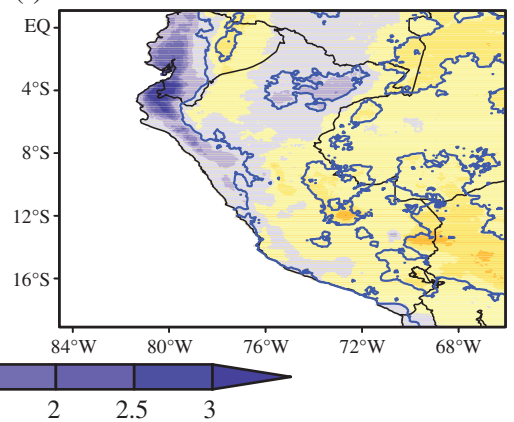

Figure 1. Linear regression coefficients between ENSO indices (Niño 3.4, C, and E) and DJF GPCP precipitation: (a, b, and c), Delaware precipitation (d, e, and f) and PISCO precipitation (g, h, and i). Values are in $\mathrm{mm} \mathrm{day}^{-1}$ for one standard deviation of each corresponding ENSO index. Blue (Red) shading represents positive (negative) precipitation anomalies in intervals of $0.5(-0.5) \mathrm{mm} \mathrm{day}^{-1}$ per standard deviation. Black contour represents the climatological isoline of $4 \mathrm{~mm} \mathrm{day}^{-1}$. Blue contours represent significant correlation between ENSO indices and precipitation at the $95 \%$ confidence level. Red boxes are associated with ITCZC index, while the orange box is linked to ITCZE index. Analysis based on the period 1980-2016. [Colour figure can be viewed at wileyonlinelibrary.com].

These rainfall patterns are consistent with their corresponding large-scale upper-level circulation. For positive values of both $\mathrm{C}$ and $\mathrm{E}$, at $200 \mathrm{hPa}$, we have the typical anticyclonic pair straddling the equator with their nuclei around $140^{\circ}$ and $130^{\circ} \mathrm{W}$, respectively (Figures 2(a) and (b)) and easterly equatorial wind anomalies extending to the far-eastern Pacific. Both signals represent a stationary Rossby wave, which forms in response to release of latent heat during intense convective activity over the central Pacific (Gill, 1980). To the east, the response generally features westerly wind anomalies around the equator, but the details of these vary over the Andes, where these westerlies are associated with reduced rainfall. In the case of $\mathrm{C}$, the westerlies are found all along the tropical Andes (Figure 2(a)), consistent with the equatorial Kelvin wave response to the convective forcing in the equatorial Pacific that in both cases extend eastward into the Maritime Continent (Chiang and Lintner, 2005). With E, westerly wind anomalies prevail over a larger part of SA, while over the Andes southwesterly wind anomalies prevail between approximately $10^{\circ}$ and $30^{\circ} \mathrm{S}$ (Figure 2(b)), but they have an easterly component to the north, indicating an anticyclonic nucleus around $15^{\circ} \mathrm{S}, 90^{\circ} \mathrm{W}$, consistent with a stationary Rossby wave response to the convective anomalies in the far-eastern Pacific (Hoskins and Ambrizzi, 1993, their Fig. 6). The westerlies over the Andes with $\mathrm{E}$ are only about half the magnitude as with $\mathrm{C}$. The above is consistent with the weak and spatially limited dry signal in the Andes from E relative to C (Lavado-Casimiro and Espinoza, 2014). Furthermore, the same upper-level westerly wind anomalies seen over Peru during both types of El Niño also are very consistent with the pattern of upper-level westerly streamflow anomalies over all of Peru documented in Tedeschi et al. (2015), who used a different methodology.

These upper-level circulation anomalies are approximately the inverse of the low-level circulation pattern for both E and C (not shown), as would be expected from the tropospheric overturning circulation response to a mid-tropospheric convective heating anomaly (Gill, 1980), which in turn dominates the vertically integrated 


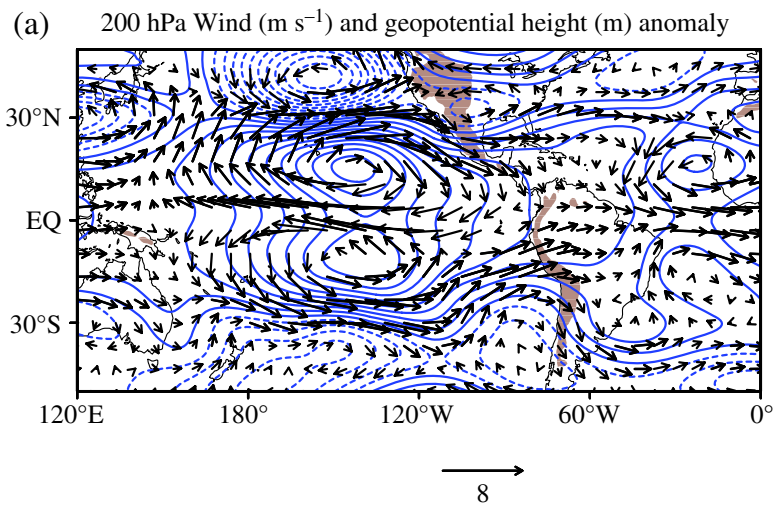

(c)

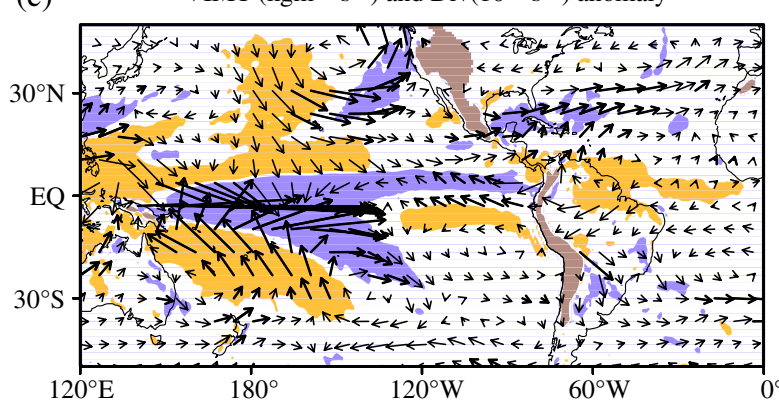

(b) $\quad 200 \mathrm{hPa}$ Wind $\left(\mathrm{m} \mathrm{s}^{-1}\right)$ and geopotential height (m) anomaly

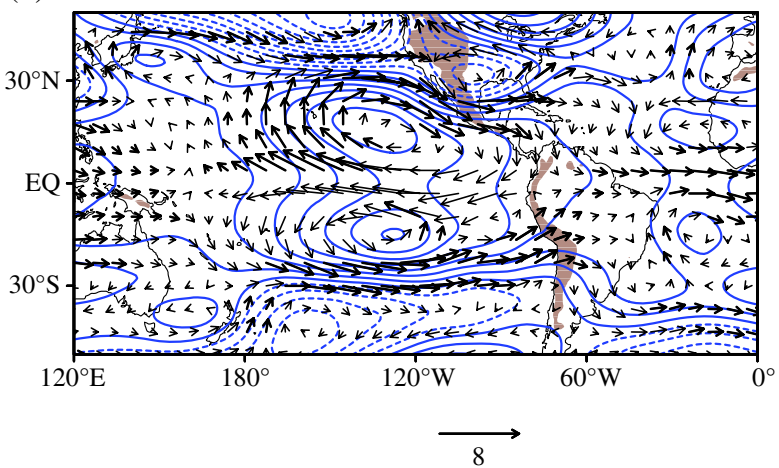

(d) VIMT $\left(\mathrm{kgm}^{-1} \mathrm{~s}^{-1}\right)$ and $\operatorname{Div}\left(10^{-6} \mathrm{~s}^{-1}\right)$ anomaly

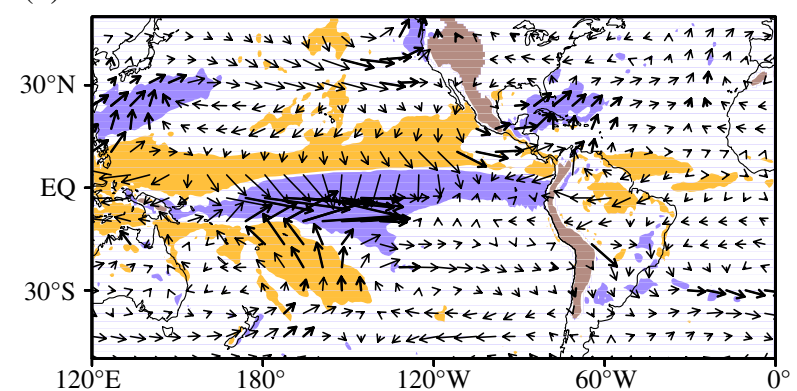

70

Figure 2. ENSO indices (C and E) regressed upon DJF ERA-Interim geopotential height and wind anomalies at $200 \mathrm{hPa}$, divergence anomalies at $850 \mathrm{hPa}$, and vertically integrated moisture transport anomalies: El Niño C (a and c) and El Niño E (b and d). Wind and vertically integrated moisture transport anomalies statistically significant at the $95 \%$ confidence level are shown in bold. Scale for wind vector (in $\mathrm{m} \mathrm{s}^{-1}$ per standard deviation) and vertically integrated moisture transport (in $\mathrm{kg} \mathrm{m}^{-1} \mathrm{~s}^{-1}$ per standard deviation) are shown below. Contour interval of geopotential height anomalies is $50 \mathrm{~m}$ per standard deviation. Shading indicates divergence anomalies above (below) $6 \times 10^{-6}\left(-6 \times 10^{-6}\right) \mathrm{s}^{-1}$ per standard deviation. Andes topography above $1500 \mathrm{~m}$ is indicated by brown shading. ERA-Interim data set were used in this analysis. Analysis based on the period 1980-2016. [Colour figure can be viewed at wileyonlinelibrary.com].

moisture transport (Figures 2(c) and (d)). Then, the response to $\mathrm{E}$ in the equatorial Pacific is dominated by westerly transport anomalies (Figure 2(d)), although this is limited to the central Pacific in the case of $\mathrm{C}$ (Figure 2(c)). As should be expected in a seasonal mean, the moisture transport anomaly convergence/divergence (Figures 2(c) and (d)) match the enhanced/reduced rainfall pattern (Figures 1(b) and (c)), allowing for the differences between the ERA-Interim and CRU data sets. The same Figures 2(c) and (d) further show the predominance of easterly transport anomalies and divergence in the Amazon within $10^{\circ}$ of the equator, although in the western Amazon we find convergence, consistent with the enhanced rainfall (Figures 1(c), (f) and (i)), probably due to the orographic effect of the Andes, blocking the Kelvin wave signal. This is opposite to the westerly pattern and divergence over the western Amazon sometimes observed after El Niño has peaked, which leads to drought in the region, although the warming of the northern tropical Atlantic plays a more dominant role in this case (Espinoza et al., 2011; Marengo and Espinoza, 2016). A northerly transport anomaly prevails east of the Andes into SESA, associated with the enhancement of the SALLJ (Silva et al., 2009), where it converges (Figures 2(c) and (d)), corresponding to the enhanced rainfall anomalies in this region (Figures 1(a)-(f); Zhou and Lau, 2001; Garreaud et al., 2003). Figures 2(c) and (d) also feature a convergence anomaly located in eastern Brazil and even reaching the South Atlantic Ocean at $25^{\circ} \mathrm{S} / 35^{\circ} \mathrm{W}$, which suggest an enhancement of the SACZ (Zhou and Lau, 2001).

\section{Connections to the Pacific ITCZ and the SPCZ}

In addition to the regression patterns between precipitation and El Niño indices (Niño 3.4, C, and E) (Figure 1), the relation between the SST indices and the ones for the ITCZ and SPCZ is shown by the linear correlation coefficients among them (Table 1). All convective indices are well correlated with Niño 3.4, while most of the convective (SPCZ and Pacific ITCZ) indices are also well correlated with both $\mathrm{C}$ and $\mathrm{E}$ indices, except for ITCZE with $\mathrm{C}$ and latW with $\mathrm{E}$, where correlations are low. An inspection of the time series shows that the E and ITCZ indices 
Table 1. DJF Pearson and Spearman correlation coefficients between several indices such as El Niño (Niño 3.4, C, and E), SPCZ indices (latW and latE) and Pacific ITCZ indices (ITCZC and ITCZE).

\begin{tabular}{lcccc}
\hline Pearson/Spearman & latW & latE & ITCZC & ITCZE \\
\hline Niño 3.4 & $\mathbf{0 . 7 4 / 0 . 8 2}$ & $\mathbf{0 . 7 6 / 0 . 7 1}$ & $\mathbf{0 . 8 3 / 0 . 7 6}$ & $\mathbf{0 . 4 4} / 0.25$ \\
C & $\mathbf{0 . 8 3 / 0 . 8 6}$ & $\mathbf{0 . 6 8} / \mathbf{0 . 6 8}$ & $\mathbf{0 . 6 2 / 0 . 6 9}$ & $0.17 / 0.14$ \\
E & $0.13 / 0.05$ & $\mathbf{0 . 4 4} / 0.04$ & $\mathbf{0 . 7 5 / 0 . 3 5}$ & $\mathbf{0 . 7 5 / 0 . 4 6}$ \\
latE & $\mathbf{0 . 6 0 / 0 . 6 6}$ & & & \\
ITCZC & $\mathbf{0 . 4 8 / 0 . 5 5}$ & $\mathbf{0 . 7 4 / 0 . 5 3}$ & & \\
ITCZE & $0.02 /-0.04$ & $\mathbf{0 . 3 2} / \mathbf{0 . 0 5}$ & $\mathbf{0 . 6 2 / 0 . 4 3}$ & \\
\hline
\end{tabular}

Values statistically significant at $95 \%$ are shown in bold. GPCP data set was used to obtain indices of SPCZ and Pacific ITCZ in this analysis. The records of ENSO indices ( $\mathrm{E}$ and $\mathrm{C}$ ) are downloaded from the Instituto Geofisico del Peru, while the El Niño 3.4 index was downloaded from Climate Prediction Center/NOAA. Analysis based on the period 1980-2016.

(Figures 3(b), (e), and (f)) have large values for the extreme 1983 and 1998 El Niños (Takahashi et al., 2011; Takahashi and Dewitte, 2016). This is also true to a lesser extent for the latE index (Figure 3(d)), whereas the latW index registers very low positive anomalies. During the 2016 El Niño, both latE and ITCZC indices register large anomalies similar to 1983 and 1998, while the ITCZE index showed weaker positive anomalies relative to these years. These results are consistent with the very strong positive SST anomalies observed in the central Pacific but not as much with the SST in the eastern Pacific in 2016. Hence, the classification of the 2016 El Niño as moderate or strong is somewhat ambiguous (L'Heureux et al., 2016). For the rank (Spearman) correlation coefficient, the large El Niños no longer have a strong effect in the calculation and the coefficients with E drop substantially, so that for ITCZC, the value becomes larger for $\mathrm{C}$ than E (Table 1). Since all of the convective indices are affected by ENSO, they are expected to be correlated among themselves, with the lowest correlation found between ITCZE and the SPCZ indices, particularly latW (Table 1). These results are in agreement with our current dynamical knowledge of the SPCZ. Vincent et al. (2011), for example, pointed out that the latW index is associated mainly with the northward displacement of the SPCZ, which is linked to vigorous convective activity over the central Pacific; whereas the zonal position of the SPCZ, which is associated with strong convective activity along the Pacific basin tends to prevail during extraordinary El Niño events and thus influences both SPCZ indices.

The results of the multiple regression using the indices of SPCZ and Pacific ITCZ show that the method generally isolates adequately the associated regional rainfall variability patterns in the tropical Pacific with some caveats (Figure 4). The ITCZE regression pattern clearly features an extensive equatorial band of positive rainfall anomalies across the central and eastern Pacific reaching the coast of northern Peru and southern Ecuador $\left(180^{\circ}-80^{\circ} \mathrm{W}\right)$ and latitudinal reduction in the mean position of the ITCZ in the central-eastern Pacific $\left(170^{\circ} \mathrm{E}-110^{\circ} \mathrm{W}\right)$, while also indicating a westward retreat of the eastern edge of the subtropical end of the SPCZ (Figure 4(d)). In the case of latE, the regression pattern also clearly depicts the northward displacement of the SPCZ between $160^{\circ} \mathrm{E}$ and $140^{\circ} \mathrm{W}$, although it also features a weak component of the equatorial enhancement associated with the eastern Pacific ITCZ (Figure 4(b)). In the case of the ITCZC index, the Figure 4(c) shows that the pattern is dominated by the enhancement on the equatorial flank of the ITCZ in the central-eastern Pacific $\left(180^{\circ}-110^{\circ} \mathrm{W}\right)$ by the reduction in the northeasterly trade winds region $\left(180^{\circ}-130^{\circ} \mathrm{W}\right.$, $0^{\circ}-15^{\circ} \mathrm{S}$ ). The same Figure 4(c) shows that ITCZC has quite different features than ITCZE because ITCZC is characterized by a precipitation reduction in the eastern equatorial Pacific and a precipitation dipole of opposite sign located on the eastern subtropical edge of the SPCZ. The results for the latW index are the most mixed, as the pattern is dominated by the precipitation enhancement in the equatorial central Pacific $\left(150^{\circ} \mathrm{E}-170^{\circ} \mathrm{W}\right)$, as well as on the equatorial flanks of the ITCZ and the SPCZ eastward of $120^{\circ} \mathrm{W}$ (Figure $4(\mathrm{a})$ ). It also includes a precipitation reduction on the poleward flank of the SPCZ, as well as over the Maritime continent between $20^{\circ} \mathrm{S}$ and $15^{\circ} \mathrm{N}$ (Figure 4(a)). Hence latW depicts a general central Pacific eastward and equatorward shift of the convection, consistent with the high correlation with the $\mathrm{C}$ index (Table 1).

Over South America, the strongest large-scale signal in the rainfall regression pattern is the drying in the northern region associated with latW (Figure 5(a)), but despite the correlation between latW and $\mathrm{C}$, the drying does not extend south of the equator and does not feature the enhancement in SESA as in the case of C (Figure 1(e)). However, latW has a somewhat clearer enhancement signal in the Mato Grosso region of central Brazil (around $15^{\circ} \mathrm{S}, 55^{\circ} \mathrm{W}$ ) and a stronger reduction in precipitation over northwestern Chile and southern Peru. The PISCO data, however, shows that the latter is more robust with C (Figure 1(h)) than with latW (Figure 6(a)), but also indicates a negative precipitation signal from latW along the northern coast of Peru (Figure 6(a)) that is not present with C (Figure 1(h)). This pattern is consistent with the northward displacement of the SPCZ, inducing large-scale subsidence along the northern Peruvian coast (Chen et al., 1999) and with the upper-level anticyclonic wind anomaly centred at $5^{\circ} \mathrm{S}$, $95^{\circ} \mathrm{W}$ (Figure 7(a)). The upper-level circulation over South America (Figure 7(a)) is characterized by westerly anomalies over the central Andes ( $30^{\circ} \mathrm{S}$-Eq.) that are consistent with the drying signal over the Andes, similar to the pattern associated with $\mathrm{C}$, but extending less far to the south (Figure 2(a)). Additional features include cyclonic anomalies off the coast of Chile $\left(35^{\circ} \mathrm{S}, 80^{\circ} \mathrm{W}\right)$ and off the coast of eastern Brazil $\left(10^{\circ} \mathrm{S}, 30^{\circ} \mathrm{W}\right)$. Over the Amazon, the anomalies are weak compared to the case of C. The drying signal in the northern Amazon and the wet anomalies to the south are consistent with the anomalous moisture divergence in the north, whose northerly component converges into SESA and eastern Brazil south of $5^{\circ} \mathrm{S}$. The drying signal along the northern coast of Peru is consistent with the divergence of the westerly transport anomalies associated with a northward confinement of the ITCZ (Figure 8(a)). 
(a)

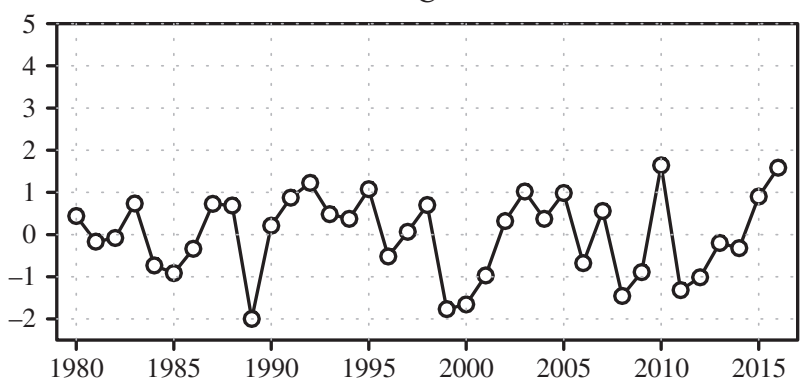

(c)

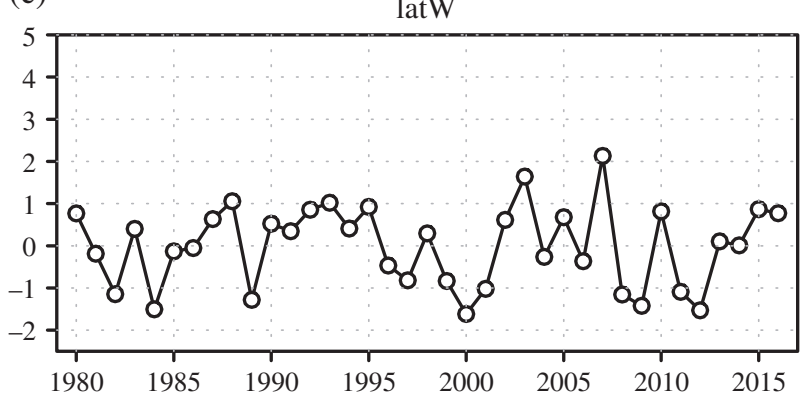

(e)

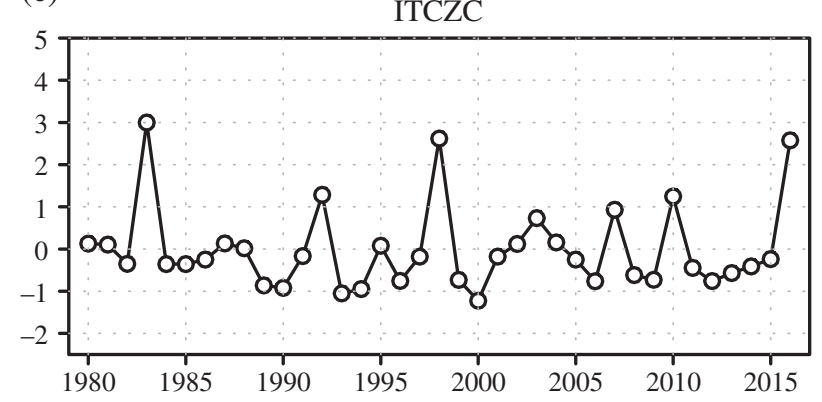

(b)

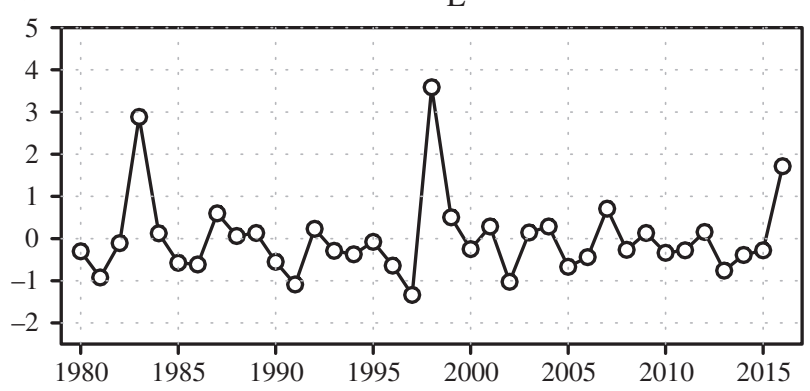

(d)

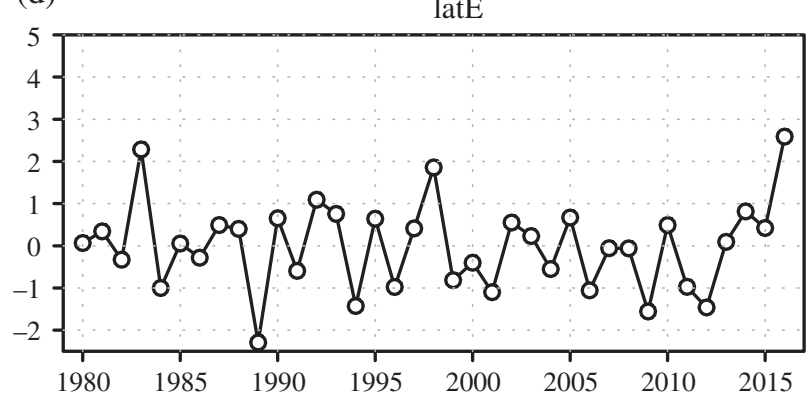

(f)

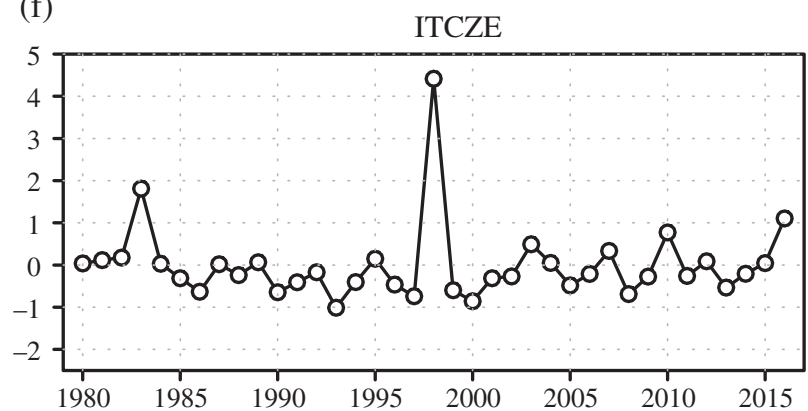

Figure 3. DJF series of standardized anomalies of (a) El Niño C, (b) El Niño E, (c) latW index, (d) latE index, (e) ITCZC index, and (f) ITCZE index. Analysis based on the period 1980-2016.

In the case of latE (Figure 5(b)), we find drying in the eastern Amazon around the equator (near $55^{\circ} \mathrm{W}$ ) and around $10^{\circ} \mathrm{S}$ in the western Amazon $\left(70^{\circ} \mathrm{W}\right)$, and with smaller intensity in central-west Brazil $\left(20^{\circ} \mathrm{S}, 54^{\circ} \mathrm{W}\right)$. On the other hand, we find a weak rainfall increase in northern and central Argentina. In Peru, latE has a dry signal in the southwestern central Andes and over the southern Amazon, as well as a weak wet signal in the northern Amazon region (Figure 6(b)), while the wet signal in northwestern Peru is probably a spurious contamination from the eastern Pacific ITCZ (Figure 4(b)). The upper-level westerly circulation anomalies (Figure 7(b)) are consistent with a Kelvin wave signal that reduces rainfall over the Andes and, by converging over the equatorial Amazon, leads to the low-level moisture transport divergence associated with the dry anomalies (Figure 8(b)).

The rainfall pattern associated with ITCZC has similar drying in the equatorial Amazon and the Andes as latE, although the signal over the Andes is stronger in Ecuador (Figures 5(c) and 6(c)). The pattern also includes enhanced rainfall in eastern Brazil $\left(25^{\circ}-5^{\circ} \mathrm{S}\right)$ and Paraguay. This north-south dipole pattern is consistent with an enhancing of SALLJ over Bolivia that provokes the northerly moisture transport anomaly between drier and wetter regions (Figure 8(c)). There is also a drying signal along the northern coast of Peru (Figure 6(c)) associated with the northward retreat of the eastern Pacific ITCZ (Figure 4(c)). The upper-level circulation features westerly anomalies over the central Andes $\left(25^{\circ} \mathrm{S}-5^{\circ} \mathrm{N}\right)$, consistent with the drying over the Andes, but its pattern is complex, suggesting that multiple atmospheric pathways lead from the ITCZC to South America (Figure 7(c)).

In the case of ITCZE, the strong increase in rainfall along the coasts of Ecuador and northern Peru (Figures 5(d) and $6(d))$ is directly associated with the southward displacement of the eastern Pacific ITCZ (Figure 4(d)). In Peru, the enhanced rainfall reaches to the higher parts of the western Andes, which is likely due to both the local effect of high SST but also aided by easterly upper-level circulation between $15^{\circ} \mathrm{S}$ and $15^{\circ} \mathrm{N}$ flanked by anticyclonic bands (Figure 7(d)), consistent with an equatorial Rossby wave response to the heating associated with the eastern Pacific ITCZ (Hoskins and Ambrizzi, 1993). Associated with this, westerly anomalies are found south of the Altiplano 
(a)

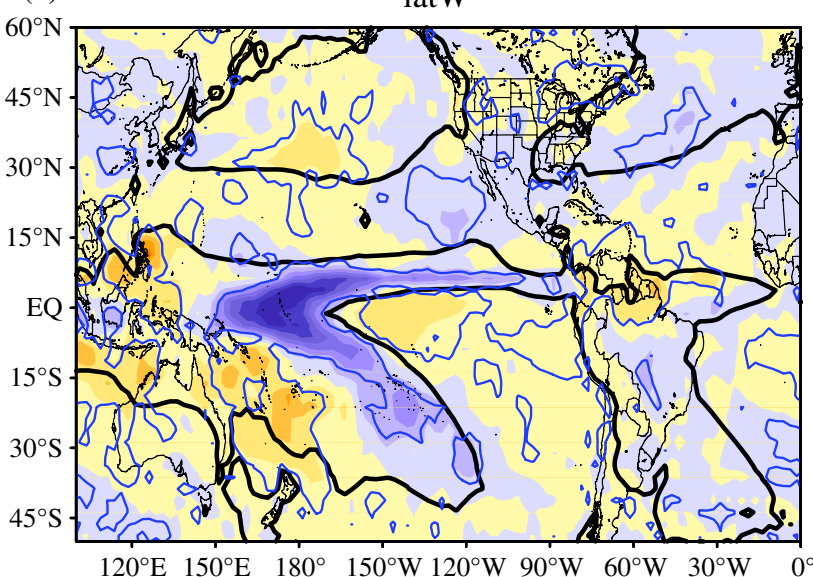

(c) ITCZC

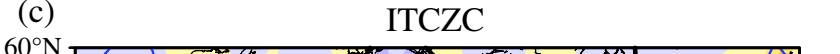

(b)

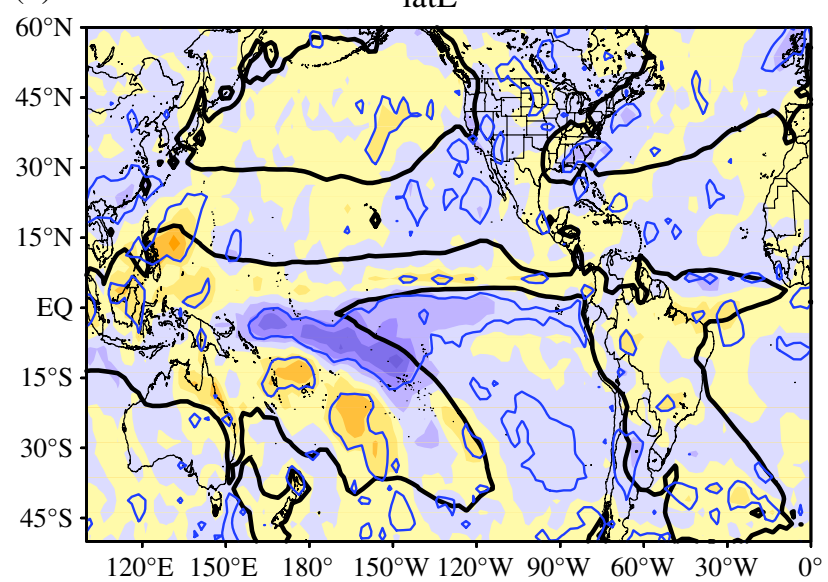

(d)

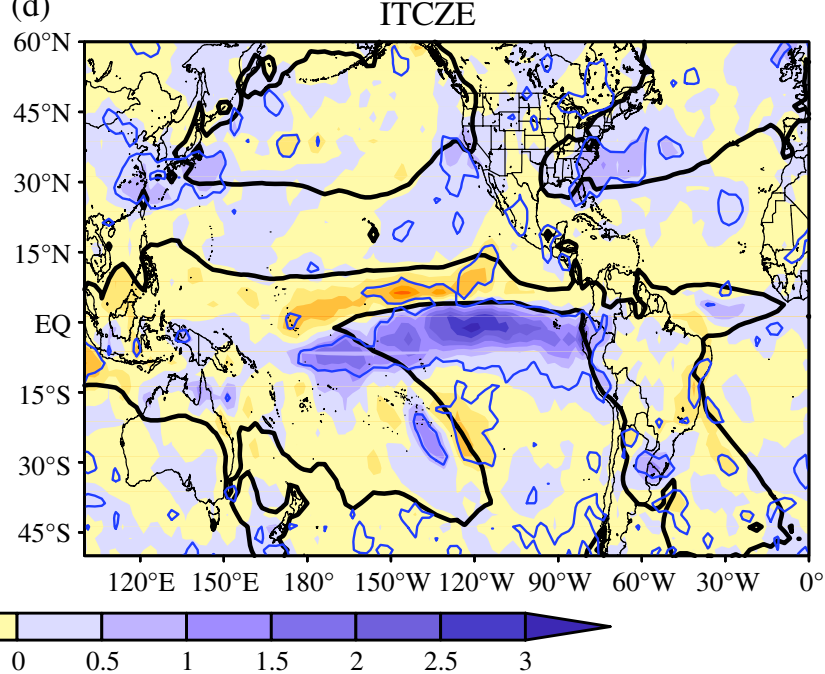

Figure 4. Regression of several indices upon DJF GPCP precipitation for (a) latW index, (b) latE index, (c) ITCZC index, and (d) ITCZE index. Scale for precipitation anomalies (in $\mathrm{mm} \mathrm{day}^{-1}$ per standard deviation). Blue contours represent significant correlation between both SPCZ and ITCZ indices and precipitation at the $95 \%$ confidence level. Red (blue) shading represents positive (negative) precipitation anomalies. Contour interval is $0.5 \mathrm{~mm} \mathrm{day}^{-1}$ per standard deviation. Black contour represents the climatological isoline of $4 \mathrm{~mm} \mathrm{day}^{-1}$. Analysis based on the period $1980-2016$. [Colour figure can be viewed at wileyonlinelibrary.com].

$\left(30^{\circ}-20^{\circ} \mathrm{S}\right.$; Figure $\left.7(\mathrm{~d})\right)$, consistent with the dry anomalies in this region (Figure 5(d)). The teleconnection effects feature dry conditions in eastern Brazil $\left(25^{\circ}-5^{\circ} \mathrm{S}\right)$ and wet conditions in SESA (northern Uruguay and Argentina, southern Brazil; around $30^{\circ} \mathrm{S}, 56^{\circ} \mathrm{W}$ ), consistent with the moisture convergence pattern that is associated with an anticyclonic low-level circulation; which is in agreement with the northerly transport anomalies into SESA and an easterly component in eastern Brazil (Figure 8(d)). This anticyclonic circulation approximately mirrors an upper-level trough (Figure 7(d)) that could be explained as a short Rossby wave response to the ITCZ heating (Silva Dias et al., 1983).

\section{Discussion}

We attempted to isolate the effects of specific aspects associated with various ENSO flavors, by analysing the influence of four indices that are correlated among them.
However, the fact that we only have 37 years for the PISCO data set is a limitation. For instance, the extreme 1997-1998 El Niño dominates the ITCZE index and the rainfall signal along the coasts of northern Peru and Ecuador, but the 1982-1983 event was just as extreme in this regard, despite its ITCZE value being less than half as large (Takahashi and Dewitte, 2016). Furthermore, extreme El Niño events in the eastern Pacific are rare (Takahashi et al., 2011) so extending the observational data sets might not be enough to account for these.

We tested the robustness of our main findings by looking at the relationship between the rainfall in South America and the E and C indices for the 1960-1980 period using the University of Delaware product (not shown) and found that the large-scale features of Figures 1(e) and (f) are well reproduced, although for $\mathrm{C}$ we find strong positive correlations in eastern Brazil (east of $55^{\circ} \mathrm{W}, 20^{\circ}-5^{\circ} \mathrm{S}$ ) and a more confined dry signal in northern South America (NSA, to the north of $2^{\circ} \mathrm{S}$ ). We note that for $\mathrm{E}$, the positive signal in the northeastern Amazon of Peru is also found for 
(a)

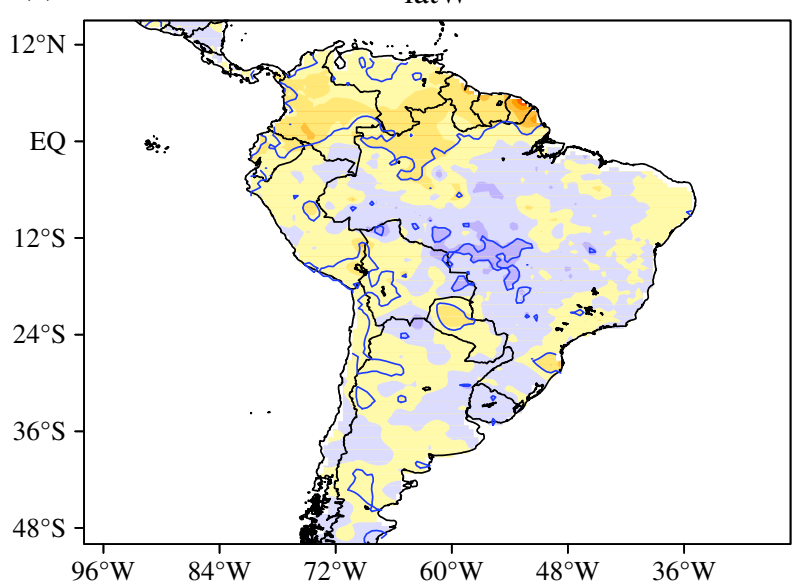

(c)

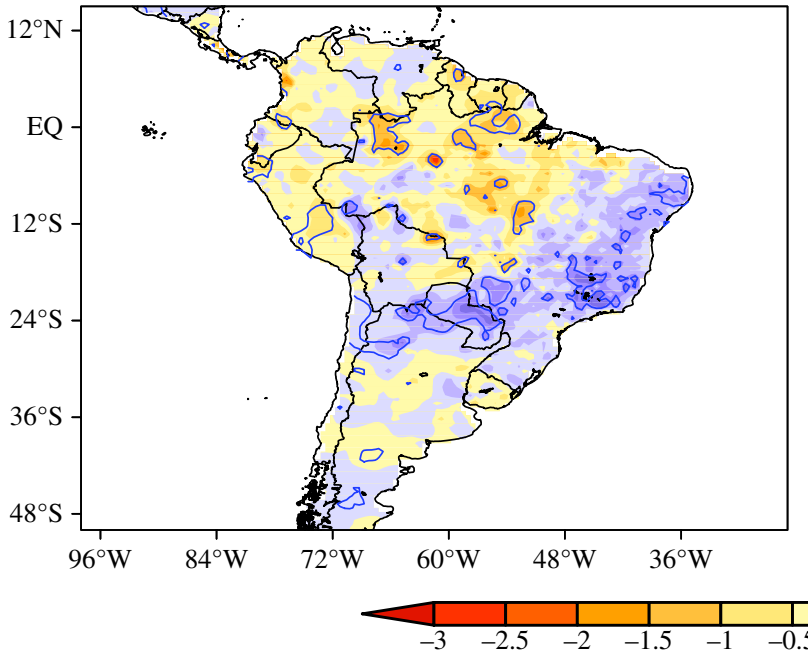

(b)

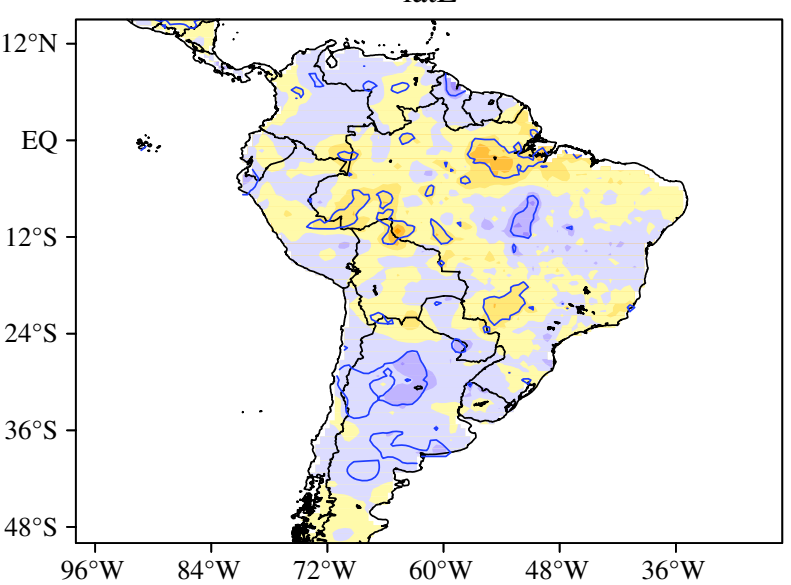

(d)

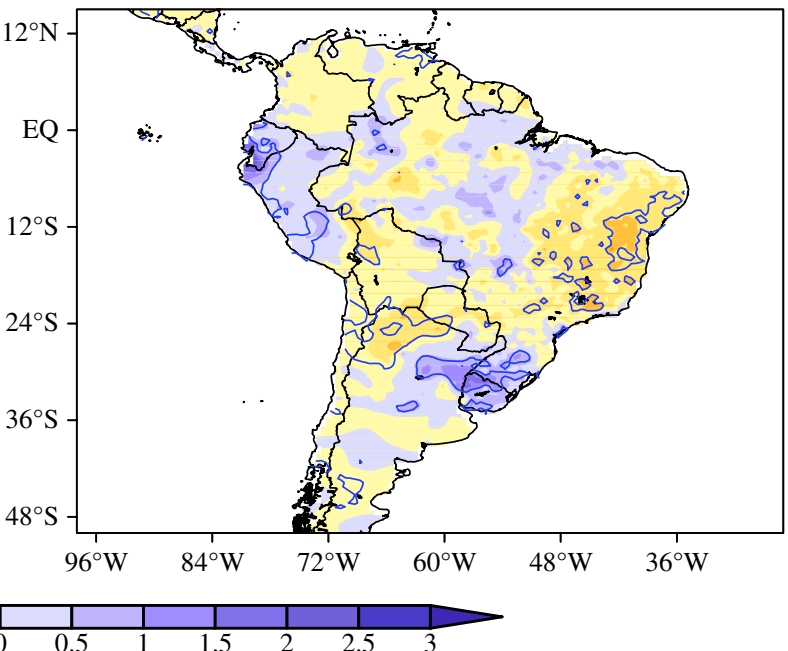

Figure 5. As in Figure 4, but for Delaware data set. Analysis based on the period 1980-2014. [Colour figure can be viewed at wileyonlinelibrary .com].

this period, consistent but stronger than for the subsequent period (Figure 1(f)).

For simplicity we have used multiple regression as our main tool, but it is well known that over the eastern equatorial Pacific and the coast of Peru, where SST is low and the atmosphere is stable, rainfall responds nonlinearly to SST, such that heavy rainfall only occurs when the absolute SST exceeds a threshold of around $26^{\circ} \mathrm{C}$ (Woodman, 1999; Takahashi, 2004; Takahashi and Dewitte, 2016). Hence, the positive and negative rainfall linear regression coefficients along the arid northern coast of Peru most likely reflect a nonlinear increase or decrease in rainfall with the corresponding indices.

Although $\mathrm{E}$ and $\mathrm{C}$ comprise a close to complete basis for describing equatorial Pacific SST variability (Takahashi et al., 2011), rainfall in the Peruvian Amazon, northern and northeastern South America in general is also affected by Atlantic SST variability, which in part is associated with ENSO (Enfield and Mayer, 1997; Saravanan and Chang, 2000; Giannini et al., 2001; Wang, 2005; Yoon, 2016). However, a description of the contribution of the
Atlantic Ocean to the inter-annual precipitation variability is beyond the scope of our current study.

Furthermore, although the four indices for the ITCZ and SPCZ would be expected to explain more variance than $\mathrm{E}$ and $\mathrm{C}$, they are partly correlated and were not designed to represent all of the degrees of freedom of the tropical Pacific rainfall variability, which explains why some features, such as the dry anomalies in the eastern Cordillera in Peru associated with C (Figure 1(h)), are not reproduced by the full set of convective indices (Figure (6)).

\section{Summary and conclusions}

The C index, which measures ENSO-related SST anomalies in the central Pacific, is associated mainly with a rainfall dipole by the north-south displacement of SPCZ. It also explains most of the significant dry anomalies seen along the tropical Andes (Bolivia, Peru, and Ecuador), southwestern Amazonia, and northernmost South America north of $10^{\circ} \mathrm{S}$ (northwestern Colombia, Venezuela, Guyana, Suriname, and French Guiana), and 
(a)

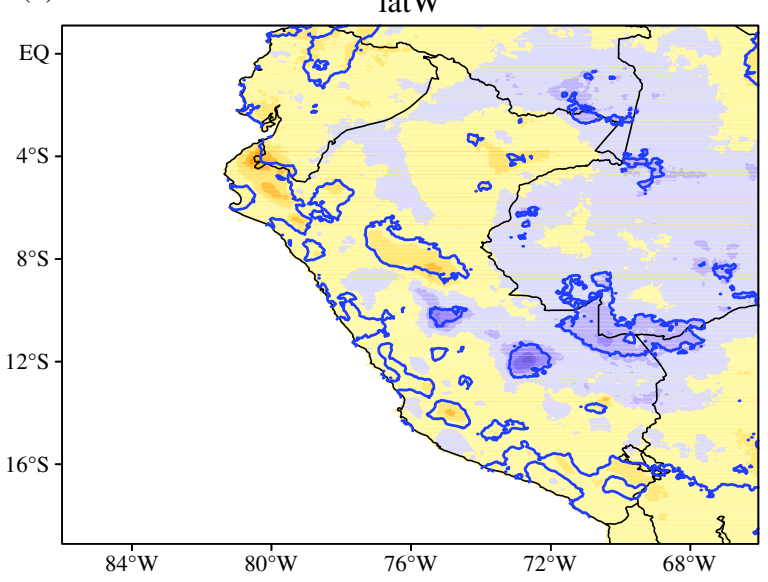

(c)

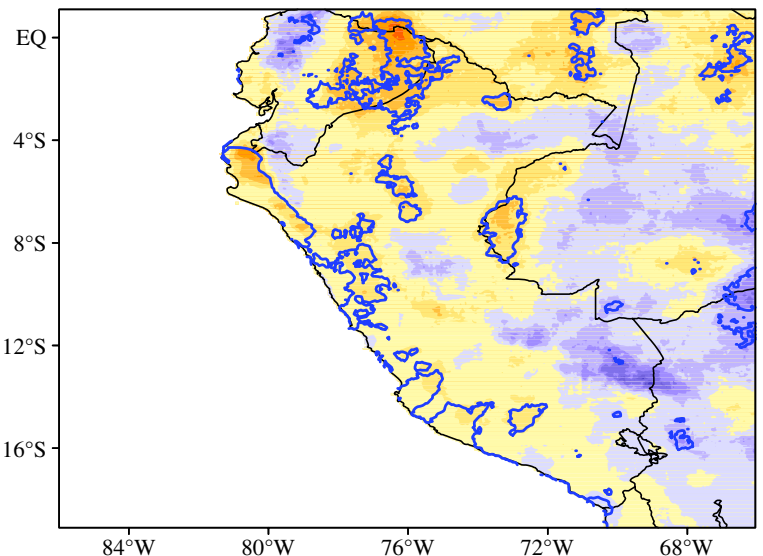

(b)

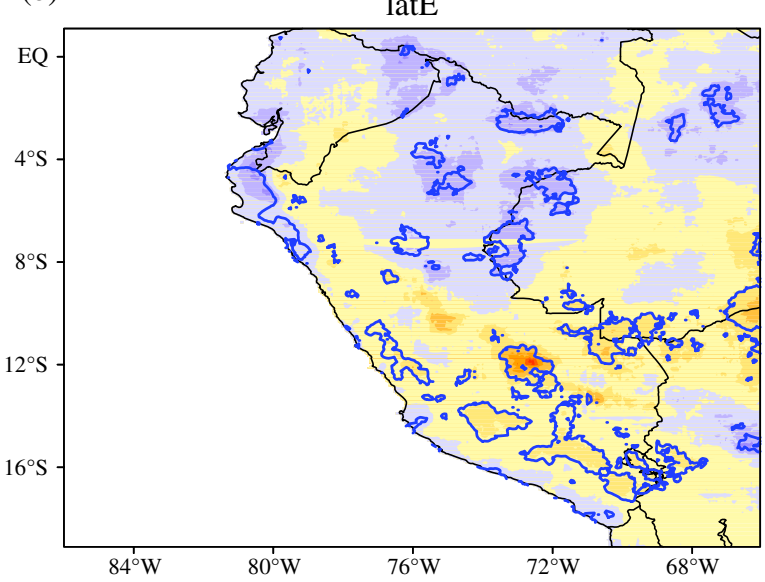

(d)

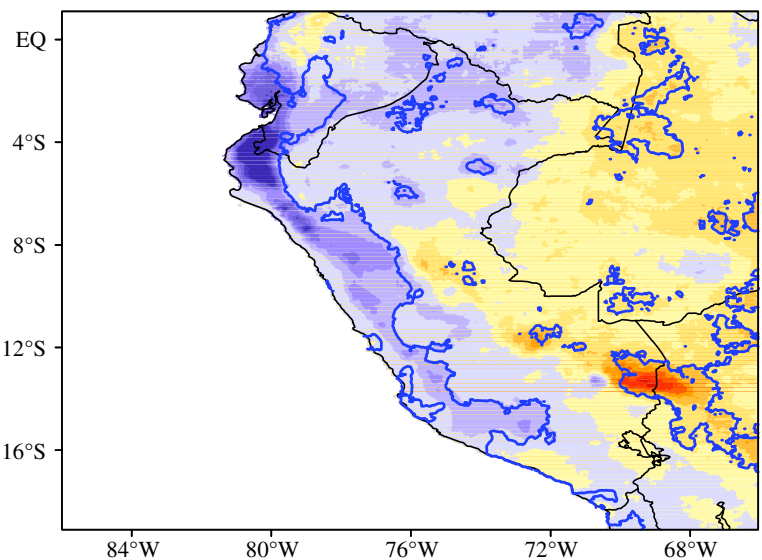

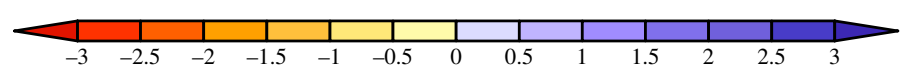

Figure 6. As in Figure 4, but for PISCO data set. Analysis based on the period 1982-2016. [Colour figure can be viewed at wileyonlinelibrary.com].

the significant wet anomalies over SESA during its positive phase. However, these signals are weaker than the relationship found with the Niño 3.4 index.

The E index, for the eastern Pacific, is better than the $\mathrm{C}$ index to characterize the zonal position of the SPCZ and the meridional displacement of the ITCZ, and is positively correlated with precipitation anomalies observed along the coast from central Peru towards the Ecuadorian coast. In addition, $\mathrm{E}$ induces significant dry anomalies in the Peruvian Altiplano, along the eastern side of the southern Andes and over the Amazon of Peru and along the Peru-Brazil boundary during its positive phase. However, these signals become insignificant when the extreme 1983 and $1998 \mathrm{El} \mathrm{Niño} \mathrm{years} \mathrm{are} \mathrm{removed} \mathrm{from} \mathrm{the} \mathrm{analysis.}$ More interestingly, the significant positive anomalies in northwestern Amazon of Peru during the positive phase of the $\mathrm{C}$ index have not been reported in previous studies and this signal still prevails, even when the 1983 and 1998 years are excluded from the analysis.

Our analysis of the regional atmospheric circulation during the austral summer over South America show clearly that the rainfall patterns associated with $\mathrm{C}$ and $\mathrm{E}$ are very consistent with the patterns of vertically integrated humidity flux and upper-level wind anomalies over South America. But, there exists a significant difference between $\mathrm{C}$ and $\mathrm{E}$ in the upper-level wind anomalies over central and southern Peru. Indeed, the positive phase of $\mathrm{C}$ is associated with westerly wind anomalies over Peru at $200 \mathrm{hPa}$, crossing the entire continent towards the Atlantic Ocean. In contrast, the positive phase of $\mathrm{E}$ is associated with southwesterly wind anomalies between $10^{\circ}$ and $30^{\circ} \mathrm{S}$ that are weaker than during positive $\mathrm{C}$ events, and are part of an anticyclonic wind anomaly centred around $15^{\circ} \mathrm{S}, 90^{\circ} \mathrm{W}$. This anticyclonic wind anomaly is caused by the propagation of Rossby wave trains, generated by convection and latent heat release over the region of warm SST anomalies in the far-eastern Pacific, into the continent.

Our multiple linear regression analysis allowed us to characterize the influence of the SPCZ on South American precipitation without consideration of the ENSO signal. Our results show that the SPCZ modulates rainfall over South America on inter-annual timescales during the austral summer. For example, the northward displacement of the SPCZ, which is represented by the index latW, induces significant dry anomalies over NSA north of $5^{\circ} \mathrm{S}$, along the coast of Ecuador and northern Peru, over 
(a)

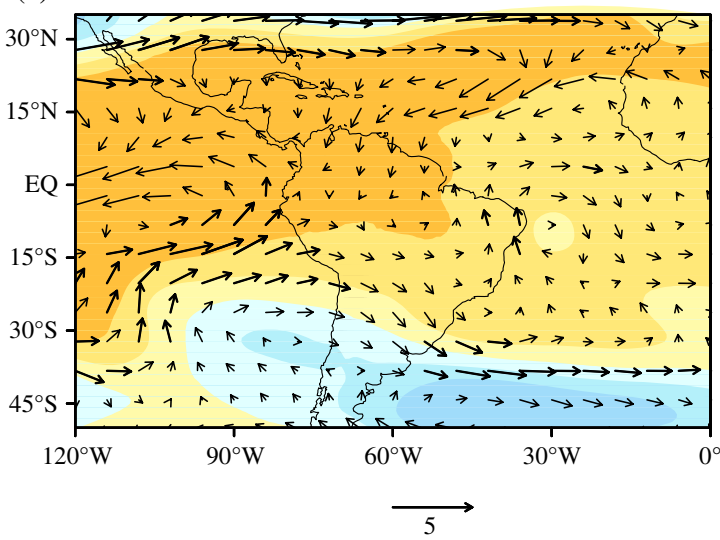

(c)

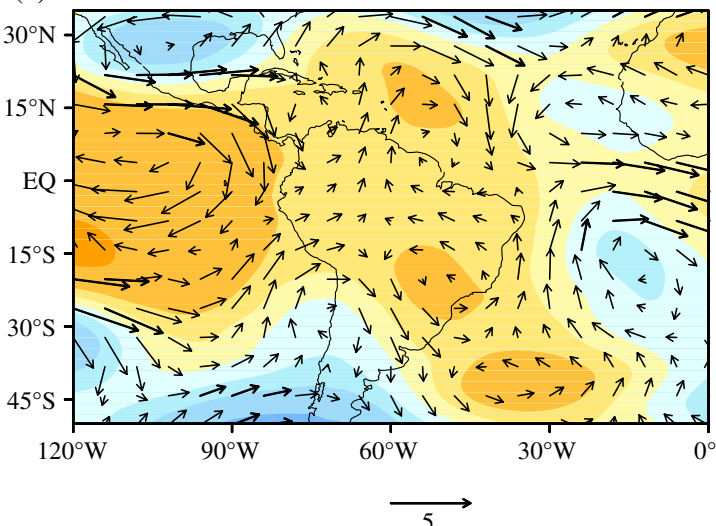

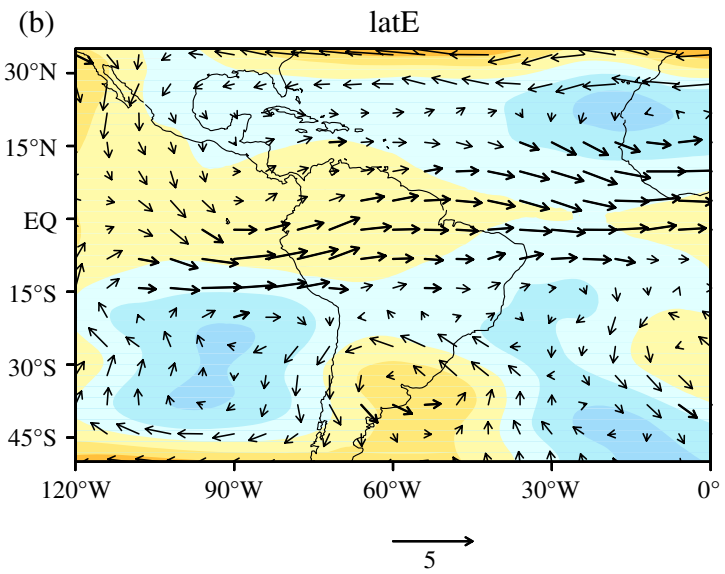

(d)

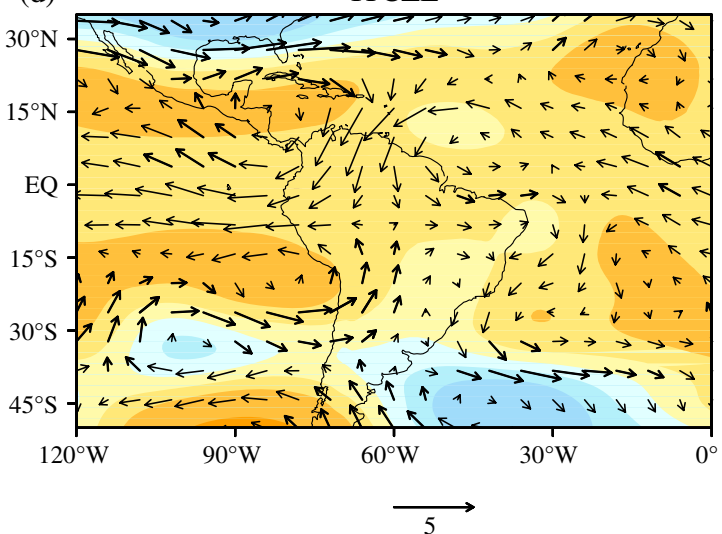

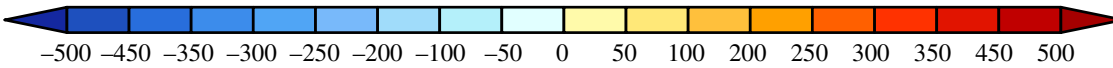

Figure 7. As in Figure 4, but for the fields of standardized anomalies of wind $\left(\mathrm{m} \mathrm{s}^{-1}\right)$ and geopotential height $(\mathrm{m})$ at $200 \mathrm{hPa}$. Both zonal and meridional wind anomalies statistically significant at the $95 \%$ confidence level are shown in bold. Shading indicates geopotential height anomalies (in $50 \mathrm{~m}$ per standard deviation). Scale for zonal and meridional wind anomalies (in $\mathrm{m} \mathrm{s}^{-1}$ per standard deviation) is shown. ERA-Interim reanalysis was used in this analysis. Analysis based on the period 1980-2016. [Colour figure can be viewed at wileyonlinelibrary.com].

the northwestern Peruvian Amazon, the Altiplano region (Peru-Bolivia) and northern Chile. Moreover, the positive phase of latW induces wet anomalies over the rest of the continent, but the anomalies are only significant around $15^{\circ} \mathrm{S}, 55^{\circ} \mathrm{W}$. In contrast, the zonal position of the SPCZ, which is linked to the index latE, affects precipitation along the coast of Peru and Ecuador, over the northeastern Peruvian Amazon, along the coast and over the Andes of Chile and central-northern Argentina. Positive values of latE produce significant dry anomalies in the western Cordillera of Peru and over the Peruvian Altiplano, as well as over the area contained between western Brazil and southeastern French Guiana. These results are consistent with the pattern of vertically integrated moisture transport and upper-level westerly wind anomalies over Peru, but are stronger in latW than in latE.

The relationship between the ITCZ and South American precipitation shows that Pacific ITCZ variability is able to modulate rainfall over South America during the austral summer on inter-annual timescales, but the two components of the ITCZ (central and eastern) show quite different correlation fields with rainfall. For example, the central part of the Pacific ITCZ (index ITCZC) during its positive phase is linked to a northward retreat of the eastern Pacific ITCZ and thus inhibits rainfall along the coast of Peru, the Ecuadorian Andes, and northern Brazil north of $12^{\circ} \mathrm{S}$, while it induces wet anomalies in Paraguay and eastern Brazil $\left(25^{\circ}-5^{\circ} \mathrm{S}\right)$ through an enhancing of SALLJ over Bolivia. At upper-tropospheric levels $(200 \mathrm{hPa})$, westerly wind anomalies dominate over all of Peru, but are weaker near the northern coast of Peru due to the presence of an anticyclonic wind anomaly located over the far-eastern Pacific. This latter is consistent with easterly vertically integrated humidity flux along the equatorial part of South America, originating over the Atlantic Ocean. In contrast, the eastern part of the Pacific ITCZ (index ITCZE) is associated with a southward displacement of the eastern Pacific ITCZ during its positive phase, which induces a significant rainfall dipole characterized by wet (dry) anomalies along the coast of Peru and the central Peruvian Andes (over NEB). These rainfall anomalies are consistent with upper-level easterly wind anomalies over Peru north of $15^{\circ} \mathrm{S}$, while southerly wind anomalies dominate over the rest of Peru, in conjunction with an anticyclonic anomaly located off the coast of southern Peru. The ITCZE index on the other hand, during its positive phase, 
(a)

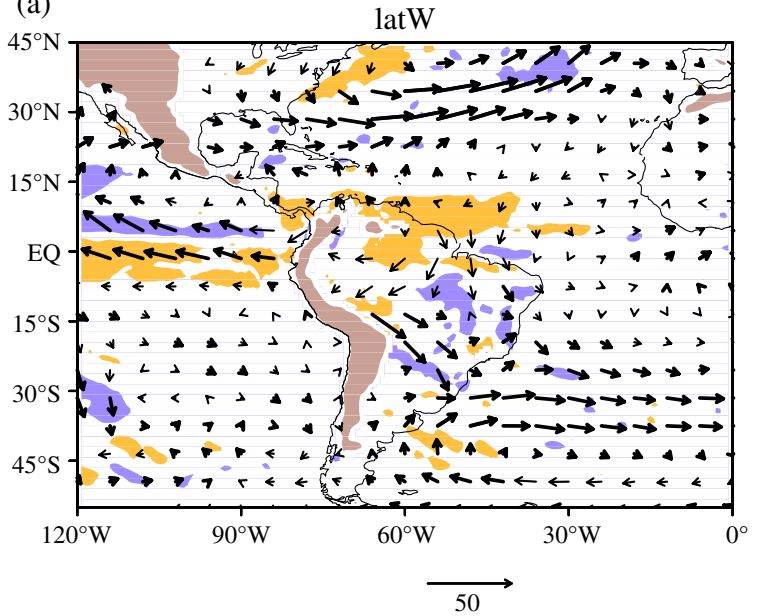

(c)

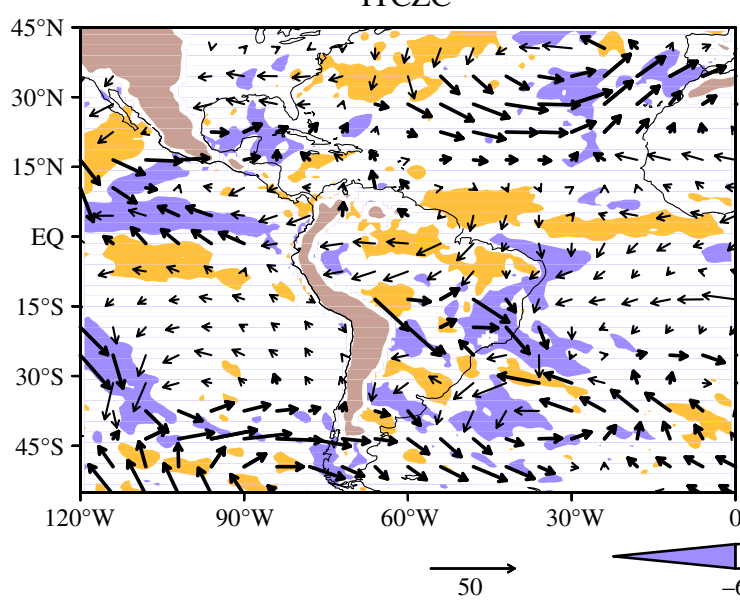

(b)

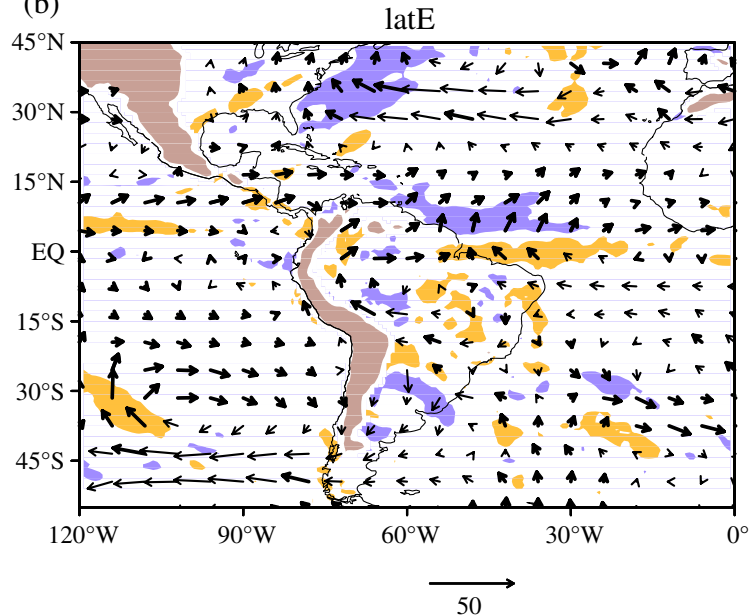

(d)

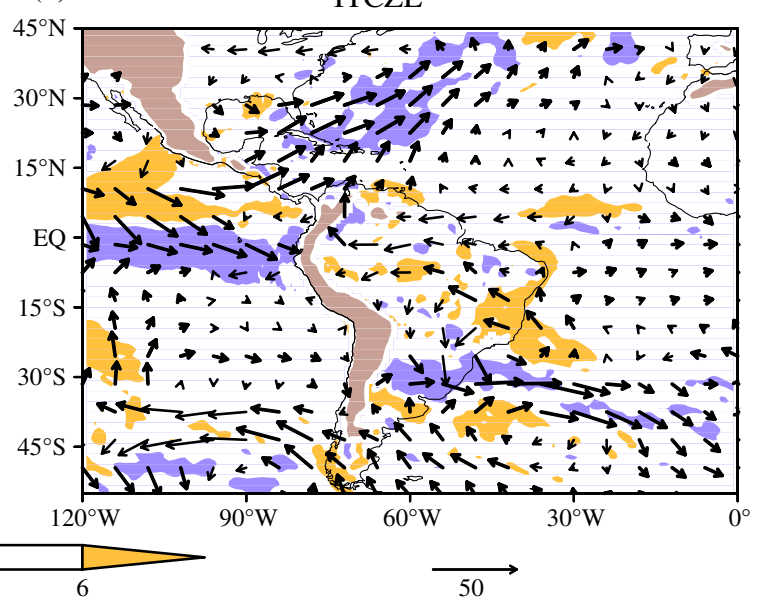

Figure 8. As in Figure 4, but for vertically integrated moisture transport and divergence. Vertically integrated moisture transport $\left(\mathrm{kg} \mathrm{m}^{-1} \mathrm{~s}^{-1} \mathrm{per}\right.$ standard deviation) anomalies statistically significant at the $95 \%$ confidence level are shown in bold. Shading represents divergence above (below) $6 \times 10^{-6} \mathrm{~s}^{-1}\left(-6 \times 10^{-6} \mathrm{~s}^{-1}\right)$ per standard deviation. ERA-Interim reanalysis was used in this analysis. Analysis based on the period $1980-2016$. [Colour figure can be viewed at wileyonlinelibrary.com].

also induces significant wet anomalies over SESA and significant dry anomalies over northern Chile, in response to an enhancement of the SALLJ and upper-level westerly wind anomalies over northern Chile, respectively.

The multiple regression with our four convective indices for the SPCZ and Pacific ITCZ as predictors cannot fully reproduce the features that result from the E and C SST indices, which indicates that they miss part of the ENSO teleconnections. Further analysis must be developed in the near future to complete the characterization of the relation between rainfall anomalies over South America and their relationship with Pacific SST anomalies, as well as other oceanic regions such as the Atlantic and Indo-Pacific Oceans (Yoon and Zeng, 2010; Lavado et al., 2012; Espinoza et al., 2014; Coelho et al., 2016).

\section{Acknowledgements}

The authors thank the PPR 068 'Reducción de vulnerabilidad y atención de emergencias por desastres’ programme. We are very grateful to two anonymous reviewers who provided us with valuable comments, which helped us to significantly advance our results and to substantially improve the manuscript. This work was performed using computational resources, HPC-Linux-Cluster, from the Laboratorio de Dinámica de Fluidos Geofísicos Computacionales (http://scah.igp.gob.pe/laboratorios/dfgc) at the Instituto Geofísico del Perú (grants 101-2014FONDECYT, SPIRALES2012 IRD-IGP, Manglares IGP-IDRC\#106714, PPR 068 programme).

\section{References}

Aceituno P. 1988. On the functioning of the Southern Oscillation in the South American sector. Part I: surface climate. Mon. Weather Rev. 116: 505-524. https://doi.org/10.1175/1520-0493 (1988) $116<0505$ :OTFOTS $>2.0 . C O ; 2$.

Adler RF, Huffman GJ, Chang A, Ferraro R, Xie P, Janowiak J, Rudolf B, Schneider U, Scott C, Bolvin D, Gruber A, Susskind J, Arkin P, Nelkin E. 2003. The version-2 Global Precipitation Climatology Project (GPCP) monthly precipitation analysis (1979-present). J. Hydrometeorol. 4: 1147-1167. https://doi.org/10.1175/1525-7541 (2003)004<1147:TVGPCP > 2.0.CO;2.

Ashok K, Behera SK, Rao SA, Weng H, Yamagata T. 2007. El Niño Modoki and its possible teleconnection. J. Geophys. Res. 112 C11007. https://doi.org/10.1029/2006JC003798. 
Berry G, Reeder MJ. 2014. Objective identification of the inter-tropical convergence zone: climatology and trends from the ERA-Interim. $J$. Clim. 27: 1894-1909. https://doi.org/10.1175/jcli-d-13-00339.1.

Borlace S, Santoso A, Cai W, Collins M. 2014. Extreme swings of the south Pacific convergence zone and the different types of El Niño events. Geophys. Res. Lett. 41: 4695-4703. https://doi.org/10.1002/ 2014GL060551.

Bretherton CS, Widmann M, Dymnikov VP, Wallace JM, Blade I. 1999. The effective number of spatial degrees of freedom of time-varying field. J. Clim. 12: 1990-2009. https://doi.org/10.1175/ 1520-0442(1999)012<1990:TENOSD>2.0.CO;2.

Capotondi A, Wittenberg AT, Newman M, Di Lorenzo E, Yu J, Braconnot P, Cole J, Dewitte B, Giese B, Guilyardi E, Jin F, Karnauskas K, Kirtman B, Lee T, Schneider N, Xue Y, Yeh S. 2015. Understanding ENSO diversity. Bull. Am. Meteorol. Soc. 96: 921-938. https:// doi.org/10.1175/BAMS-D-13-00117.1.

Carranza L. 1891. Contracorriente maritima observada en Payta y Pacasmayo. Bol. Soc. Geogr. Lima 1: 344-345.

Carvalho LMV, Jones C, Liebmann B. 2004. The south Atlantic convergence zone: intensity, form, persistence, and relationships with intra-seasonal to inter-annual activity and extreme rainfall. J. Clim. 17: $88-108 . \quad$ https://doi.org/10.1175/1520-0442(2004)017,0088: TSACZI.2.0.CO;2.

Chatterjee S, Hadi AS. 1986. Influential observations, high leverage points, and outliers in linear regression. Stat. Sci. 1: 379-416.

Chen T, Weng S, Schubert S. 1999. Maintenance of austral summertime upper-tropospheric circulation over tropical South America: the Bolivian high-Nordeste low system. J. Atmos. Sci. 56: 2081-2100. https:// doi.org/10.1175/1520-0469(1999)056<2081:MOASUT>2.0.CO;2.

Chiang JCH, Lintner BR. 2005. Mechanisms of remote tropical surface warming during El Niño. J. Clim. 18: 4130-4149. https://doi.org/10 $.1175 /$ JCLI3529.1.

Chiodi AM, Harrison DE. 2015. Global seasonal precipitation anomalies robustly associated with El Niño and La Niña Events - an OLR perspective. J. Clim. 28: 6133-6159. https://doi.org/10.1175/JCLI-D14-00387.1.

Coelho CAS, de Olivera CP, Ambrizzi T, Reboita MS, Carpenedo CB, Silveira JL, Nobile AC, Albertani L, de Souza M, Mosso LM, Da Rocha RP, Rehbein A. 2016. The 2014 southeast Brazil austral summer drought: regional scale mechanisms and teleconnections. Clim. Dyn. 46(11): 3737-3752.

Córdoba-Machado S, Palomino-Lemus R, Gámiz-Fortis SR Castro-Díez Y, Esteban-Parra MJ. 2015. Influence of tropical Pacific SST on seasonal precipitation in Colombia: prediction using El Niño and El Niño Modoki. Clim. Dyn. 44: 1293-1310. https://doi .org/10.1007/s00382-014-2232-3.

Dee DP, Uppala SM, Simmons AJ, Berrisford P, Poli P, Kobayashi S, Andrae U, Balmaseda MA, Balsamo G, Bauer P, Bechtold P, Beljaars ACM, van de Berg L, Bidlot J, Bormann N, Delsol C, Dragani R, Fuentes M, Geer AJ, Haimberger HSB, Hersbach H, Hólm EV, Isaksen L, Kllberg P, Köhler M, Matricardi M, McNally AP, Monge-Sanz BM, Morcrette JJ, Park BK, Peubey C, de Rosnay P, Tavolato C, Thépaut JN, Vitart F. 2011. The ERA-Interim reanalysis: configuration and performance of the data assimilation system. $Q . J$. R. Meteorol. Soc. 137: 553-597. https://doi.org/10.1002/qj.828.

Douglas MW, Mejia J, Ordinola N, Boustead J. 2009. Synoptic variability of rainfall and cloudiness along the coasts of northern Peru and Ecuador during the 1997/1998 El Niño event. Mon. Weather Rev. 137: $116-136$.

Eguiguren V. 1894. Las lluvias en Piura. Bol. Soc. Geogr. Lima 4: 241-258.

Enfield DB, Mayer DA. 1997. Tropical Atlantic sea surface temperature variability and its relation to El Niño-Southern Oscillation. J. Geophys. Res. 102(C1): 929-945.

Espinoza JC, Ronchail J, Guyot JL, Cochonneau G, Naziano F, Lavado W, De Olivera E, Pombosa R, Vauchel P. 2009. Spatio-temporal rainfall variability of Amazon basin countries (Brazil, Peru, Bolivia, Colombia and Ecuador). Int. J. Climatol. 29: 1574-1594. https://doi .org/10.1002/joc. 1791 .

Espinoza JC, Ronchail J, Guyot JL, Junquas C, Vauchel P, Lavado W, Drapeau G, Pombosa R. 2011. Climate variability and extreme drought in the upper Solimões River (western Amazon basin): understanding the exceptional 2011 drought. Geophys. Res. Lett. 38(13): L13406. https://doi.org/10.1029/2011GL047862.

Espinoza JC, Marengo JA, Ronchail J, Molina J, Noriega L, Guyot JL. 2014. The extreme 2014 flood in south-western Amazon basin: the role of tropical-subtropical south Atlantic SST gradient. Environ. Res. Lett. 9: 124007.
Espinoza JC, Chavez S, Ronchail J, Junquas C, Takahashi K, Lavado W. 2015. Rainfall hotspots over the southern tropical Andes: spatial distribution, rainfall intensity and relations with large-scale atmospheric circulation. Water Resour. Res. 51: 9379-9401. https://doi.org/10.1002/ 2014WR016273.

Francou B, Vuille M, Favier V, Cáceres B. 2004. New evidence for an ENSO impact on low latitude glaciers: Antizana 15, Andes of Ecuador, $0^{\circ} 28^{\prime}$ S. J. Geophys. Res. 109: D18106. https://doi.org/10 .1029/2003JD004484.

Frappart F, Papa F, Santos da Silva J, Ramillien G, Pringent C, Seyler F, Calmant S. 2012. Surface freshwater storage and dynamics in the Amazon basin during the 2005 exceptional drought. Environ. Res. Lett. 7: 044010. https://doi.org/10.1088/1748-9326/7/4/044010.

Garreaud RD. 1999. A multi-scale analysis of the summertime precipitation over the central Andes. Mon. Weather Rev. 127: 901-921. https:// doi.org/10.1175/1520-0493(1999)127<0901:MAOTSP>2.0.CO;2.

Garreaud RD, Aceituno P. 2001. Interannual rainfall variability over the South American Altiplano. J. Clim. 14: 2779-2789. https://doi.org/10 $.1175 / 1520-0442(2001) 014,2779$ :IRVOTS.2.0.CO;2.

Garreaud RD, Vuille M, Clement AC. 2003. The climate of the Altiplano: observed current conditions and mechanisms of past changes. Palaeogeogr. Palaeoclimatol. Palaeoecol. 194: 5-22. https://doi.org/ 10.1016/S0031-0182(03)00269-4

Garreaud RD, Vuille M, Compagnucci R, Marengo J. 2009. Present-day South American climate. Palaeogeogr. Palaeoclimatol. Palaeoecol. 281: 180-195. https://doi.org/10.1016/j.palaeo.2007.10.032.

Giannini A, Chiang JCH, Cane MA, Kushnir Y, Seager R. 2001. The ENSO teleconnection to the tropical Atlantic Ocean: contributions of the remote and local SSTs to rainfall variability in the tropical Americas. J. Clim. 14: 4530-4544. https://doi.org/10. 1175/1520-0442(2001)014<4530:TETTTT>2.0.CO;2.

Gill AE. 1980. Some simple solutions for heat-induced tropical circulation. Q. J. R. Meteorol. Soc. 106: 447-462. https://doi.org/10.1002/qj 49710644905.

Goldberg RA, Tisnado G, Scofield RA. 1987. Characteristics of extreme rainfall events in northwestern Peru during 1982-1983 El Niño period. J. Geophys. Res. Oceans 13C: 14225-14241. https://doi.org/ 10.1029/JC092iC13P14225.

Grimm AM. 2011. Interannual climate variability in South America: impacts on seasonal precipitation, extreme events, and possible effects of climate change. Stoch. Environ. Res. Risk Assess. 25: 537-554. https://doi.org/10.1007/s00477-010-0420-1

Grimm AM, Ambrizzi T. 2009. Teleconnections into South America from the tropics and extratropics on interannual and intraseasonal timescales. In Past Climate Variability in South America and Surrounding Regions: From the Last Glacial Maximum to the Holocene, Vimeux F, Sylvestre F, Khodri M (eds). Springer: Apeldoorn, The Netherlands, 159-191. https://doi.org/10.1007/978-90-4812672-9 7.

Hastenrath S, Greischar L. 1993. Circulation mechanisms related to northeast Brazil rainfall anomalies. J. Geophys. Res. 98: 5093-5102.

Hastenrath S, Heller L. 1977. Dynamics of climatic hazards in northeast Brazil. Q. J. R. Meteorol. Soc. 103: 77-92.

Hoskins BJ, Ambrizzi T. 1993. Rossby wave propagation on a realistic longitudinally varying flow. J. Atmos. Sci. 50(12): 1661-1671. https:// doi.org/10.1175/1520-0469(1993)050<1661:RWPOAR>2.0.CO;2.

Huffman GJ, Bolvin DT, Nelkin EJ, Wolff DB, Adler RF, Gu G, Hong Y, Bowman KP, Stocker EF. 2007. The TRMM Multisatellite Precipitation Analysis (TMPA): quasi-global, multiyear, combined-sensor precipitation estimates at fine scales. J. Hydrometeorol. 5: 1117-1130. https://doi.org/10.1175/JHM560.1.

Instituto Geofísico del Perú. 2005a. Atlas climatológico de precipitaciones y temperaturas en la Cuenca del Río Mantaro. CONAM, Lima, Perú, 107 pp. http://www.met.igp.gob.pe/publicaciones/2000_2007/ Atlas_Climatico.pdf (accessed 12 December 2015).

Instituto Geofísico del Perú. 2005b. Vulnerabilidad y adaptación al cambio climático en la cuenca del río Mantaro, Fondo Editorial. CONAM, Lima, Peru. 104 pp. http://www.met.igp.gob.pe/publicaciones/ 2000 2007/Vulnerabilidad_actual_futura.pdf (accessed 12 December 2015).

Jia L, Yang X, Vecchi GA, Gudgel RG, Delworth TL, Rosati A, Stern WF, Wittenberg AT, Krishnamurthy L, Zhang S, Msadek R, Kapnick S, Underwood S, Zeng F, Anderson WG, Balali V, Dixon K. 2015. Improved seasonal prediction of temperature and precipitation over land in a high-resolution GFDL climate model. J. Clim. 28: 2044-2062. https://doi.org/10.1175/JCL-D-14-00112.1.

Jiménez-Muñoz JC, Mattar C, Barichivich J, Santamaría-Artigas A, Takahashi K, Malhi Y, Sobrino JA, Van der Schrier G. 2016. 
Record-breaking warming and extreme drought in the Amazon rainforest during the course of El Niño 2015-2016. Sci. Rep. 6: 33130. https://doi.org/10.1038/srep33130.

Johnson NC, Kosaka Y. 2016. The role of eastern equatorial Pacific convection on the diversity of boreal winter El Niño teleconnection patterns. Clim. Dyn. 47: 3737-3765. https://doi.org/10.1007/s00382016-3039-1

Kao HY, Yu JY. 2009. Contrasting eastern-Pacific and central-Pacific types of ENSO. J. Clim. 22(3): 615-632. https://doi.org/10.1175/ 2008JCLI2309.1.

L'Heureux ML, Takahashi K, Watkins AB, Barnston AG, Becker EJ, Di Liberto TE, Gamble F, Gottschalck J, Halpert MS, Huang B, Mosquera-Vásquez K, Wittenberg AT. 2016. Observing and predicting the 2015-2016 El Niño. Bull. Am. Meteorol. Soc. https://doi.org/ 10.1175/BAMS-D-16-0009.1.

Lagos P, Silva Y, Nickl E, Mosquera K. 2008. El Niño related precipitation variability in Peru. Adv. Geosci. 14: 231-237. https://doi.org/10 .5194/adgeo-14-231-2008.

Larkin NK, Harrison DE. 2005. Global seasonal temperature and precipitation anomalies during El Niño autumn and winter. Geophys. Res. Lett. 32: L16705. https://doi.org/10.1029/2005GL022860.

Lavado WS, Ronchail J, Labat D, Espinoza JC, Guyot JL. 2012. Basin-scale analysis of rainfall and runoff in Peru (1969-2004): Pacific, Titicaca and Amazonas drainages. Hydrol. Sci. J. 57: 625-642. https://doi.org/10.1080/02626667.2012.672985.

Lavado W, Labat D, Ronchail J, Espinoza JC, Guyot JL. 2013. Trends in rainfall and temperature in the Peruvian Amazon-Andes basin over the last 40 years (1965-2007). Hydrol. Process. 41: 2944-2957. https://doi.org/10.1002/hyp.9418.

Lavado W, Fernandez C, Vega F, Caycho T, Endara S, Huerta A, Obando OF. 2016. PISCO: Peruvian interpolated data of the SENAMHI's climatological and hydrological observations. Precipitación v1.0. Servicio Nacional de Meteorología e Hidrología, pp. 1-4.

Lavado-Casimiro W, Espinoza JC. 2014. Impact of El Niño and La Niña on rainfall in Peru. Rev. Bras. Meteorol. 29: 171-182.

Marengo JA, Espinoza JC. 2016. Extreme seasonal droughts and floods in Amazonia: causes, trends and impacts. Int. J. Climatol. 36: 1033-1050. https://doi.org/10.1002/joc.4420.

Marengo JA, Soares WR, Saulo C, Nicolini M. 2004. Climatology of the low-level east of the Andes as derived from the NCEP-NCAR reanalyses: characteristics and temporal variability. J. Clim. 17(12): 2261-2280. https://doi.org/10.1175/1520-0442(2004)017<2261: COTLJE $>2.0 . \mathrm{CO} ; 2$

Matsuura K, Willmott CJ. 2015. Terrestrial air temperature and precipitation: monthly and annual time series (1950-2014). http:// climate.geog.udel.edu/ climate/html_pages/Global2014/README. GlobalTsP2014.html (accessed 5 December 2015).

McPhaden MJ, Zebiak SE, Glantz SE. 2006. ENSO as an integrating concept in Earth Science. Science 314(5806): 1740-1745.

Moura A, Shukla J. 1981. On the dynamics of droughts in northeast Brazil: observations, theory, and numerical experiments with a general circulation model. J. Atmos. Sci. 38: 2653-2675.

Münnich M, Neelin JD. 2005. Seasonal influence of ENSO on the Atlantic ITCZ and equatorial South America. Geophys. Res. Lett. 32: L21709. https://doi.org/10.1029/2005GL023900.

Philander SG. 1990. El Niño, La Niña, and the Southern Oscillation. Academic Press: Cambridge. 293 p..

Poveda G, Mesa OJ, Salazar LF, Arias PA, Moreno HA, Vieira SC, Agudelo PA, Toro VG, Alvarez JF. 2005. The diurnal cycle of precipitation in the tropical Andes of Colombia. Mon. Weather Rev. 133: $228-240$

Rau P, Bourrel L, Labat D, Melo P, Dewitte B, Frappart F, Lavado W, Felipe O. 2017. Regionalization of rainfall over the Peruvian Pacific slope and coast. Int. J. Climatol. 37: 143-158. https://doi.org/10.1002/ joc. 4693 .

Robertson AW, Mechoso CR. 2000. Interannual and interdecadal variability of the south Atlantic convergence zone. Mon. Weather Rev. 128: 2947-2957. https://doi.org/10.1175/1520-0493(2000)128<2947: IAIVOT $>2.0 . \mathrm{CO} ; 2$.

Ropelewski CF, Halpert MS. 1987. Global and regional scale precipitation patterns associated with the El Niño/Southern Oscillation. Mon. Weather Rev. 115: 1606-1626. https://doi.org/10.1175/ 1520-0493(1987)115<1606:GARSPP > 2.0.CO;2.

Saravanan R, Chang P. 2000. Interaction between tropical Atlantic variability and El Niño-Southern Oscillation. J. Clim. 13: 2177-2194. https://doi.org/10.1175/1520-0442(2000)013<2177:IBTAVA>2.0. $\mathrm{CO} ; 2$.
Segura H, Espinoza JC, Junquas C, Takahashi K. 2016. Evidencing decadal and interdecadal hydroclimatic variability over the central Andes. Environ. Res. Lett. 11: 094016.

Silva GAM, Ambrizzi T. 2006. Inter-El Niño variability and its impact on the South American low-level jet east of the Andes during austra summer - two case studies. Adv. Geosci. 6: 283-287. https://doi.org/ 1680-7359/adgeo/20006-6-283.

Silva Dias PL, Schubert WH, De Maria M. 1983. Large-scale response of the tropical atmosphere to transient convection. J. Clim. 40: 2689-2707. https://doi.org/10.1175/1520-0469(1983)040<2689: LSROTT>2.0.CO;2.

Silva Y, Takahashi K, Chávez R. 2008. Dry and wet rainy seasons in the Mantaro river basin (central Peruvian Andes). Adv. Geosci. 14: 261-264.

Silva GAM, Ambrizzi T, Marengo JA. 2009. Observational evidences on the modulation of the South American low level jet east of the Andes according the ENSO variability. Ann. Geophys. 27 645-657.

Sulca J, Vuille M, Silva Y, Takahashi K. 2016. Teleconnections between the Peruvian central Andes and northeast Brazil during extreme rainfall events in austral summer. J. Hydrometeorol. 17: 499-515. https:// doi.org/10.1175/JHM-D-15-0034.1.

Sun D, Xue F, Zhou TJ. 2013. Impacts of two types of El Niño on atmospheric circulation in the Southern Hemisphere. Adv. Atmos. Sci. 30(6): 1732-1742. https://doi.org/10.1007/s00376-013-2287-9.

Takahashi K. 2004. The atmospheric circulation associated with extreme rainfall events in Piura, Peru, during 1997-1998 and 2002 El Niño events. Ann. Geophys. 22: 3917-3926.

Takahashi K, Battisti DS. 2007. Processes controlling the mean tropical Pacific precipitation pattern. Part II: the SPCZ and the southeast Pacific dry zone. J. Clim. 20: 5696-5706. https://doi.org/10.1175/ 2007JCLI1656.1.

Takahashi K, Dewitte B. 2016. Strong and moderate nonlinear El Niño regimes. Clim. Dyn. 46(5): 1627-1645. https://doi.org/10.1029/ 2011GL047364.

Takahashi K, Montecinos A, Goubanova K, Dewitte B. 2011. ENSO regimes: reinterpreting the canonical and Modoki El Niño. Geophys. Res. Lett. 38: L10704. https://doi.org/10.1029/2011GL047364.

Tedeschi RG, Collins M. 2016. The influence of ENSO on South American precipitation during austral summer and autumn in observations and models. Int. J. Climatol. 36: 618-635. https://doi.org/10.1002/joc .4371 .

Tedeschi RG, Cavalcanti IFA, Grimm AL. 2013. Influence of two types of ENSO on South American precipitation. Int. J. Climatol. 33: 1382-1400. https://doi.org/10.1002/JOC.3519.

Tedeschi RG, Grimm AM, Cavalcanti IFA. 2015. Influence of central and east ENSO on extreme events of precipitation in South America during austral spring and summer. Int. J. Climatol. 35: 2015-2064. https://doi.org/10.1002/joc.4106.

Trenberth KE, Caron JM. 2000. The Southern Oscillation revisited sea level pressures, surface temperatures, and precipitation. J. Clim. 13: 4358-4365. https://doi.org/10.1175/1520-0442(2000)013<4358: TSORSL $>2.0 . \mathrm{CO} ; 2$.

Trenberth KE, Stepaniak DP. 2001. Indices of El Niño evolution. J. Clim. 14: 1697-1701. https://doi.org/10.1175/1520-0442(2001)014<1697: LIOENO>2.0.CO;2.

Trenberth KE, Branstator GW, Karoly D, Kumar A, Lau N, Ropelewski C. 1998. Progress during TOGA in understanding and modelling global teleconnections associated with tropical sea surface temperatures. J. Geophys. Res. 103(C7): 14291-14324.

Van der Wiel K, Matthews AJ, Joshi MM, Stevens DP. 2016. Why the south Pacific convergence zone is diagonal? Clim. Dyn. 46: 1683-1698. https://doi.org/10.1007/s00382-015-2668-0.

Vera C, Silvestri G, Barros V, Carril A. 2004. Differences in El Niño response over the Southern Hemisphere. J. Clim. 17(9): 1741-1753. https://doi.org/10.1175/1520-0442(2004)017<1741:DIENRO> 2.0.CO;2.

Vincent EM, Lengaigne M, Menkes CE, Jourdain NC, Marchesiello P, Madec G. 2011. Interannual variability of the south Pacific convergence zone and implications for tropical cyclone genesis. Clim. Dyn. 36(9): 1881-1896. https://doi.org/10.1007/s00382-009-0716-3.

Vuille M. 1999. Atmospheric circulation over the Bolivian Altiplano during dry and wet periods and extreme phases of the Southern Oscillation. Int. J. Climatol. 19: 1579-1600. https://doi.org/10.1002/ (SICI)1097-0088(19991130)19:14,1579::AID-JOC441.3.0.CO;2-N.

Vuille M, Keimig F. 2004. Interannual variability of summertime convective cloudiness and precipitation in the central Andes derived from ISCCP-B3 data. J. Clim. 17: 3334-3348. https://doi.org/10.1175/ 1520-0442(2004)017,3334:IVOSCC.2.0.CO;2. 
Vuille M, Bradley RS, Keimig F. 2000a. Interannual climate variability in the central Andes and its relation to tropical Pacific and Atlantic forcing. J. Geophys. Res. 105(12): 447-460. https://doi.org/10.1029/ $2000 J D 900134$.

Vuille M, Bradley RS, Keimig F. 2000b. Climate variability in the Andes of Ecuador and its relation to tropical Pacific and Atlantic sea surface temperatures anomalies. J. Clim. 13: 2520-2535. https:// doi.org/10.1175/1520-0442(2000)013<2520:CVITAO>2.0.CO;2.

Vuille M, Kaser G, Juen I. 2008. Glacier mass balance variability in the Cordillera Blanca, Peru and its relationship with climate and the large-scale circulation. Global Planet. Change 62(1-2): 14-28. https://doi.org/10.1016/j.gloplacha.2007.11.003.

Wang C. 2005: ENSO, Atlantic climate variability, and the Walker and Hadley circulations. In Diaz HF, Bradley RS. The Hadley Circulation: Present, Past and Future. Kluwer Academic Publishers: The Netherlands. 173-202.. https://doi.org/10.1007/978-1-40202944-8_7

Widlansky MJ, Webster PJ, Hoyos CD. 2011. On the location and orientation of the south Pacific convergence zone. Clim. Dyn. 36(3) 561-578. https://doi.org/10.1007/s00382-010-0871-6.
Woodman R. 1999. Modelo Estadístico para el pronóstico de las precipitaciones en la costa norte. In Proceedings of I encuentro de Universidades del Sur (RUPSUR), Piura. http://www.igp.gob.pe/rupsur.pdf (accessed 20 May 2016).

Xie P, Arkin PA. 1997. Global precipitation: a 17-year monthly analysis based on gauge observations, satellite estimates, and numerical model outputs. Bull. Am. Meteorol. Soc. 78: 2539-2558. https://doi.org/10 .1175/1520-0477(1997)078,2539:GPAYMA.2.0.CO;2.

Yoon JH. 2016. Multi-model analysis of the Atlantic influence on southern Amazon rainfall. Atmos. Sci. Lett. 17: 122-127. https://doi.org/10 $.1002 /$ asl.600

Yoon JH, Zeng N. 2010. An Atlantic influence on Amazon rainfall. Clim. Dyn. 34: 249-264. https://doi.org/10.1007/s00382-009-0551-6.

Zhou J, Lau KM. 2001. Principal modes of interannual and decadal variability of summer rainfall over South America. Int. J. Climatol. 21: 1623-1644. https://doi.org/10.1002/joc.700. 